\title{
The Temple of Millions of Years of the Pharaoh Thutmose III (Luxor) An Update on the Research
}

\author{
Myriam Seco Álvarez, Javier Martínez Babón
}

\begin{abstract}
This paper presents the most up to date discussion on the architecture of the temple of Millions of Years of Thutmose III, which has been investigated by the Spanish-Egyptian joint project since 2008. The first archaeological works took place at the site at the end of the nineteenth century and during the first decades of the twentieth century. Twelve seasons of the resumed research have brought, e.g. some completely new data concerning buildings related to the temple (i.e. the administrative building outside the southern enclosure wall, workshops north of the upper courtyard, and a house of the Ramesside priest called Khonsu at the northeast of the second courtyard), and allowed for the reconstruction of the course of the enclosure wall of the complex, as well as for some architectural restoration works. This paper also offers an overview through some of the most important finds collected so far during our research (e.g. fragments of reliefs, stelae and statues, inscribed and decorated lintels, foundation deposit, stoppers, ostraca, graffiti, and fragments of papyri) and presents the first results of their analysis: how these materials allow us to better understand the history and administration of the temple as well as what data they provide concerning the priests and the rituals which took place there.
\end{abstract}

Keywords: New Kingdom Egypt, temple, Thutmose III, West Bank, Thebes

Myriam Seco Álvarez, University of Seville, Seville; msalvarez@us.es; (D) 0000-0002-5469-1666

Javier Martínez Babón, Egyptian Museum of Barcelona, Barcelona; jmartinezegypt@gmail.com

The Henket-ankh temple (hwt Hnkt- 'nh-Mn-hpr-R', 'the temple which endows (Menkheperre)| with life') is located in a wealthy enclave of ancient western Thebes, between the hills of the Asasif and Khokha, where the cultivation area met the desert. It was built over a necropolis dated to the Middle Kingdom. The temple and the necropolis were cut into the bedrock, as can be clearly observed in the southwestern part of the site. In this area, part of the enclosure wall is carved from the bedrock, over which the mudbricks were laid. 


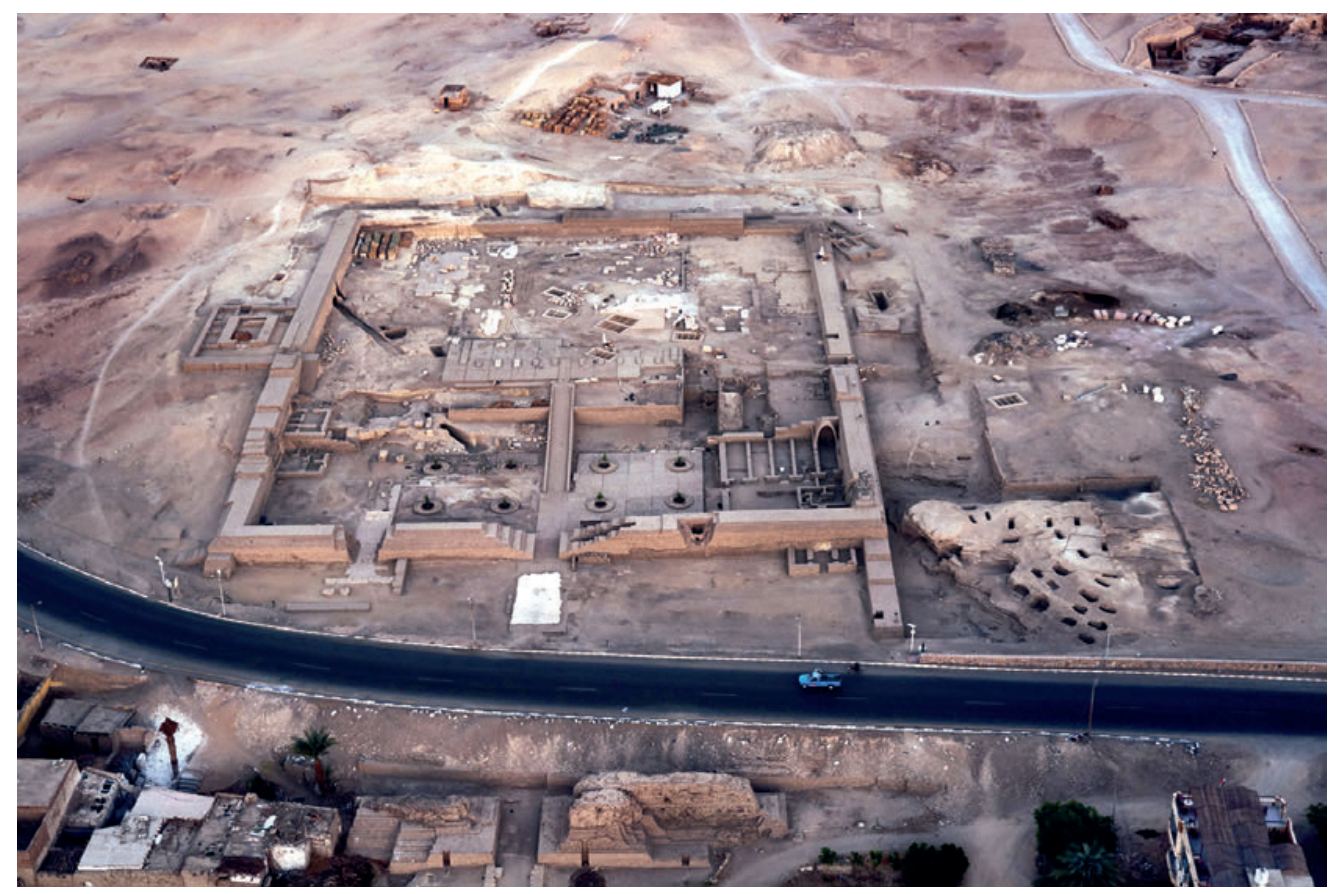

1. Aerial photo of the temple made in 2018 (Phot. J. Pablo Moreira (C) Thutmosis III Temple Project).

The construction technique was adapted, therefore, to the existing terrain: the founders of the monument shaped the bedrock before they added architectural structures in stone or in mudbrick (Figs 1-2).

The architects designed this temple on three different levels, extending between the pylon located to the east and the chapels built in the west. ${ }^{1}$ The second to the third levels were connected by a ramp. Unfortunately, little can be said of the connection between the first and second levels since a modern road crosses the first courtyard of the temple, which makes archaeological work here impossible. The difference in elevation between the ground level and the lowermost part of the temple, i.e. the area of the entrance pylon, and the sanctuary located in the uppermost terrace, is about $7.3 \mathrm{~m}$.

\section{PREVIOUS WORKS}

The temple was included by Richard Lepsius in his map of Thebes in $1844,{ }^{2}$ while three different teams worked there throughout the late nineteenth and first half of the twentieth century. In 1888 and 1889, Georges Daressy excavated architectural remains bonded to

\footnotetext{
${ }^{1}$ Very similar to what we find in the Hatshepsut's temple at Deir el-Bahari; see: Naville 1895; see also: Wysocki 1992: 233-254, Pls 42-47; 1986: 213-228.

${ }^{2} \mathrm{~L} D$ I, Pl. 73.
} 


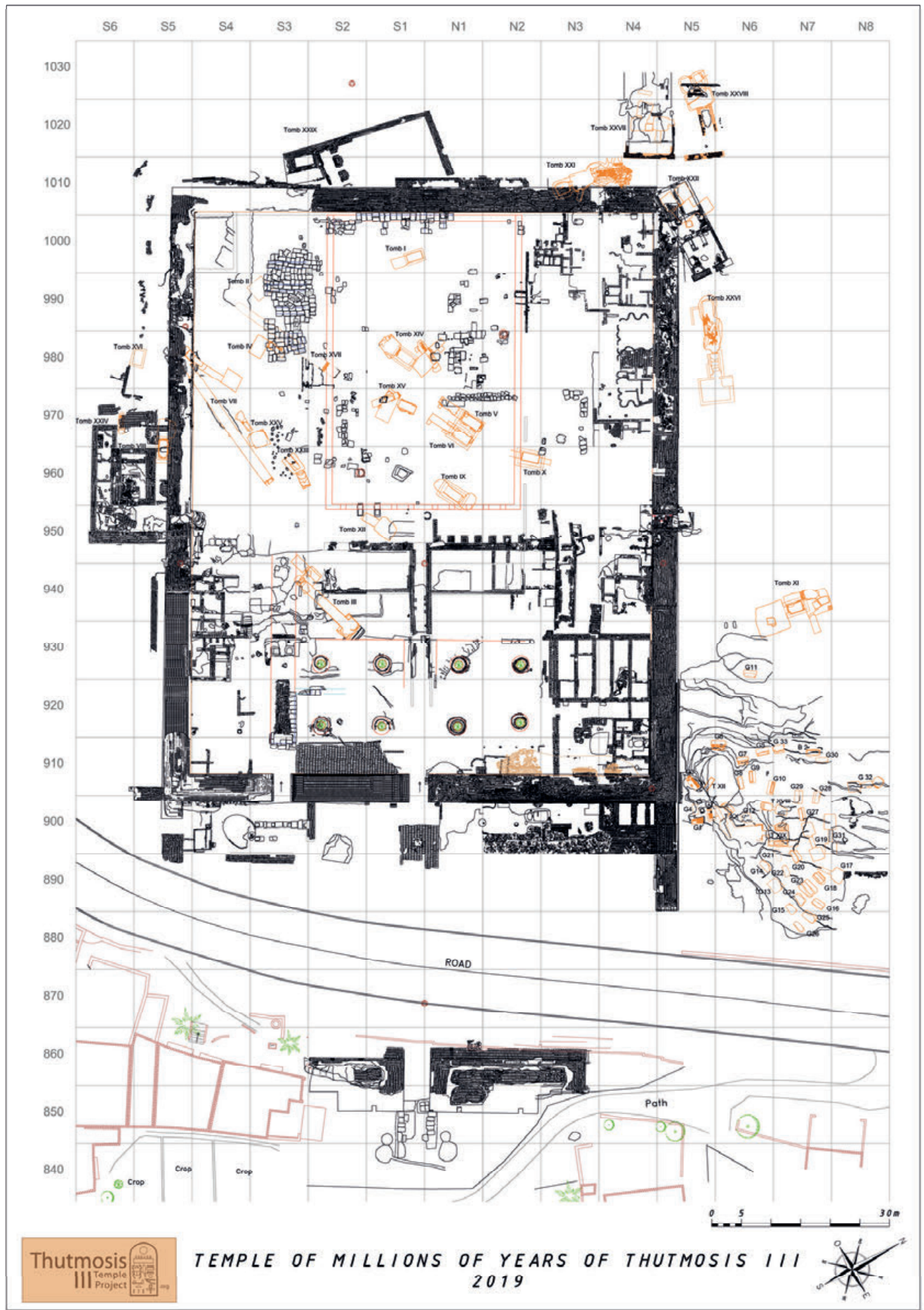

2. General plan of the temple (Surveyor: J. Tre García; drawing: E. Úbeda (C Thutmosis III Temple Project). 
the northern enclosure wall. ${ }^{3}$ In 1905, Arthur Weigall, who was the chief inspector of the Antiquities Service, worked at various sections of the temple, locating new structures, two foundation deposits and a tomb from the Middle Kingdom. ${ }^{4}$ His report was focused on the importance of movable finds, which included fragments of statues and stelae with names of important royal personalities of the first half of the Eighteenth Dynasty. Herbert Ricke carried out four campaigns over three years $\left(1934,1936\right.$ and 1937) at this monument. ${ }^{5}$ His main objective was to establish a sequence of the construction phases of the temple. For many years, his publication has been the most prominent reference to the Temple of Millions of Years of Thutmose III. After Ricke, research at the site was suspended for several decades.

The windblown sand once again covered the ruins of the temple and the complex was split into two parts by a road leading to the Valley of the Kings. What had been one of the most sacred temples of ancient Thebes quickly fell into neglect. ${ }^{6}$

\section{SYNTHESIS ON THE CONSTRUCTION PHASES}

According to Ricke, the temple was constructed in three phases, with all of them dating to the reign of Thutmose III. However, it must be noted that activity of later rulers is also well documented at the site, as will be pointed out below.

In the first phase distinguished by Ricke, which took place during the period of co-regency of Hatshepsut and Thutmose III, part of the bedrock, especially in the southwestern area, was lowered to facilitate the construction of the enclosure wall. Moreover, the area was divided into two levels connected by a ramp: a court and a terrace. At the same time the mudbrick enclosure wall was constructed, which was up to $5 \mathrm{~m}$ thick at the base, gradually narrowing upwards, and was at least $10 \mathrm{~m}$ high. The oldest enclosure wall encircles an area measuring $106 \mathrm{~m}$ from east to west and around $87.5 \mathrm{~m}$ from north to south. Traces of plastering affixed to the mudbricks is preserved on various parts of this wall. ${ }^{7}$

The second phase is dated to the first years of the sole rule of Thutmose III, and perhaps around the time of his sed-festival. ${ }^{8}$ This included the enlargement of the temple to the east and the construction of a large mudbrick pylon. The north and south enclosure walls were extended 53.25 meters towards the pylon, thus encircling the lowermost terrace.

The third phase took place at the end of the pharaoh's reign, probably around the years 49 or 50. It is documented by the opening of an entrance in the southern half of the east enclosure wall of the second courtyard. ${ }^{9}$ The entrance led to a new ramp, which allowed access to the area of a sanctuary dedicated to Hathor.

3 Daressy 1926: 13-16.

${ }^{4}$ Weigall 1906: 121-141; 1907: 286; see also: Legrain 1906.

${ }^{5}$ Ricke 1938.

${ }^{6}$ See: Maruéjol 2007: 239-242; see also: Legrain 1906: 186-187. They point out how the temple was considered one of the great monuments of the land and was serviced by a special priesthood.

7 See: Navarro et al. 2014: 27-38.

${ }^{8}$ For the discussion on this pharaoh's sed-festival(s) see, e.g.: Chapon 2018a: 138, nn. 66-68.

${ }^{9}$ Ricke 1938: 24. 
To the three main construction phases, one should add some later activities: walls built of mudbricks stamped by Amenhotep IV, and a house of Khonsu, the first priest of this temple in the time of Ramesses II. Mudbricks stamped with this pharaoh's throne name have also been found in the area.

\section{DESCRIPTION OF THE TEMPLE}

\section{THE ENTRANCE PYLON}

The entrance pylon of the temple was built, as mentioned above, of mudbricks (Fig. 3). Its southern wing is extremely damaged due to the erosion and modern construction on top of it. Three corners of the northern wing were identified during excavations, which allows us to reconstruct each wing as $26.75 \mathrm{~m}$ long and $9 \mathrm{~m}$ wide. ${ }^{10}$ On the outside face of the north wing, there is a part of the base of a stand for a flagpole.

In the entrance some large blocks of sandstone that were part of the pavement can still be seen. An alignment of sandstone blocks was also located to the east of the entrance, on both its sides (Fig. 4). At the outer ends of these alignments, the stones were irregularly cut. Many limestone fragments, ${ }^{11}$ decorated with good quality reliefs and inscriptions, with bold carving on fine grain limestone, were also found scattered by the pylon door area.

In front of the pylon, two large pits, $3.5 \mathrm{~m}$ in diameter and sunken into the bedrock, were discovered. Both were excavated to a depth of $4.5 \mathrm{~m}$, where the water table was reached. These pits were filled with the fertile soil of the Nile and were probably used as large tree planters, ${ }^{12}$ although neither tree roots nor any remains corroborating this hypothesis were recorded. Being positioned symmetrically in front of the entrance, these trees probably had a decorative function as well as a symbolic one.

\section{THE FIRST COURTYARD}

The first courtyard and the pylon date to the second phase of the temple construction. This is evidenced by the fact that the two mudbrick walls delimiting the first courtyard were added to and not bonded to the original eastern enclosure wall.

At the northwest of the courtyard, there was a mudbrick structure with three rooms, probably storerooms, one of which showed evidence of a vaulted ceiling (Fig. 5).

${ }^{10}$ See: Seco Álvarez et al. 2012-2013: 330-331. See also Hölscher 1934: Pl. 33 who describes the pylon of the Temple of Horemheb as of a very similar dimensions to that of Thutmose III. Both were already compared in: Ricke 1938: 19. Ricke tried to reconstruct the dimensions of the pylon, although at that time it was impossible due to problems with the peasants in the area; see: Ricke 1938: 19.

${ }^{11}$ The type of used limestone has not been identified yet since work on these blocks started only during the 2019 archaeological field season and will be continued in the next one.

${ }^{12}$ They were very eroded because of the old floods of the Nile. For examples of tree planters, see: Arnold 1979: 144-145; Jacquet 1994: 21-22, Pls 38, 42. 


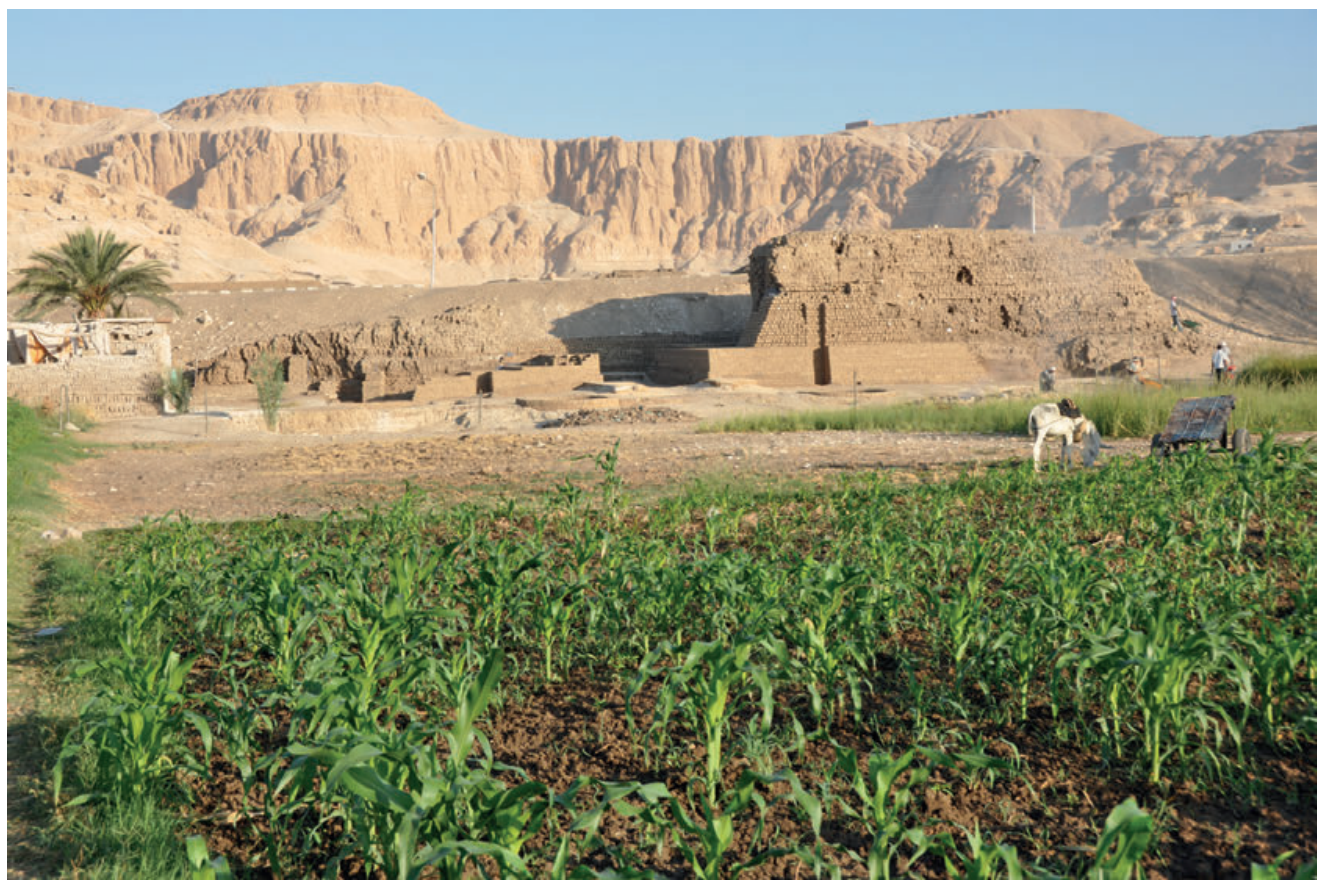

3. Pylon of the Thutmose III temple, view from the East (Phot. M. Seco Álvarez (C) Thutmosis III Temple Project).

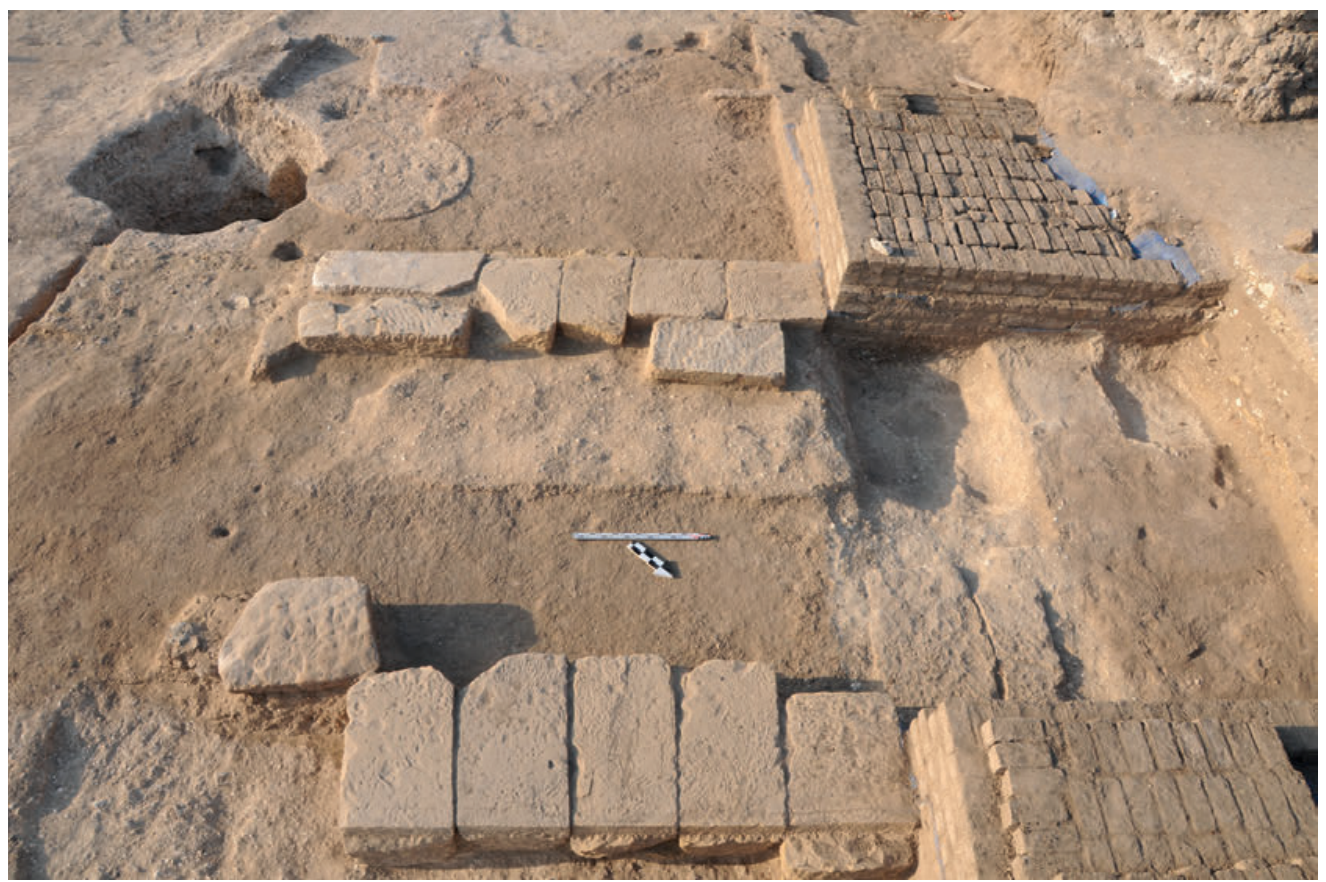

4. Some large sandstone blocks from the pylon entrance (Phot. I. Noureddine (C) Thutmosis III Temple Project). 


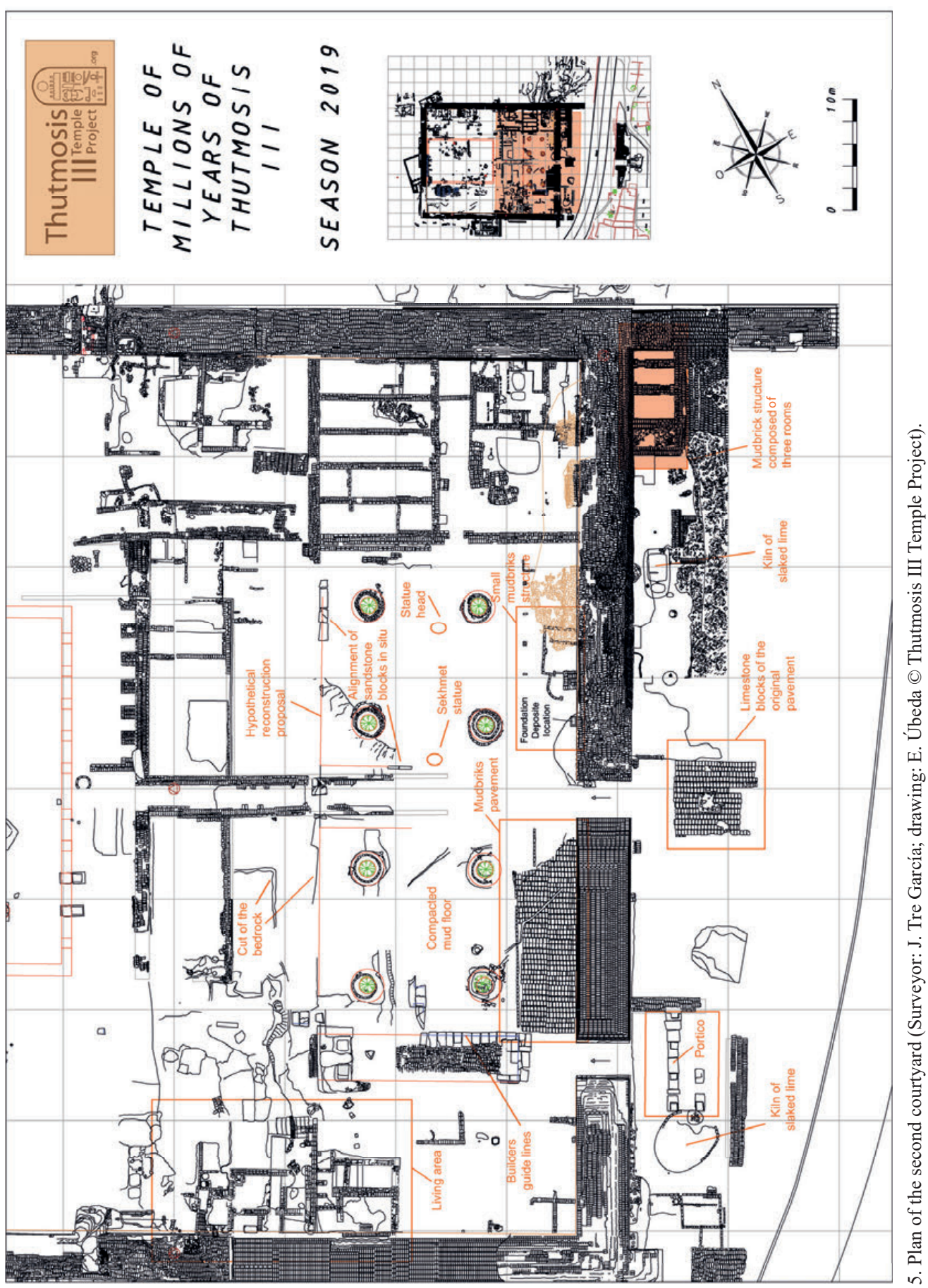




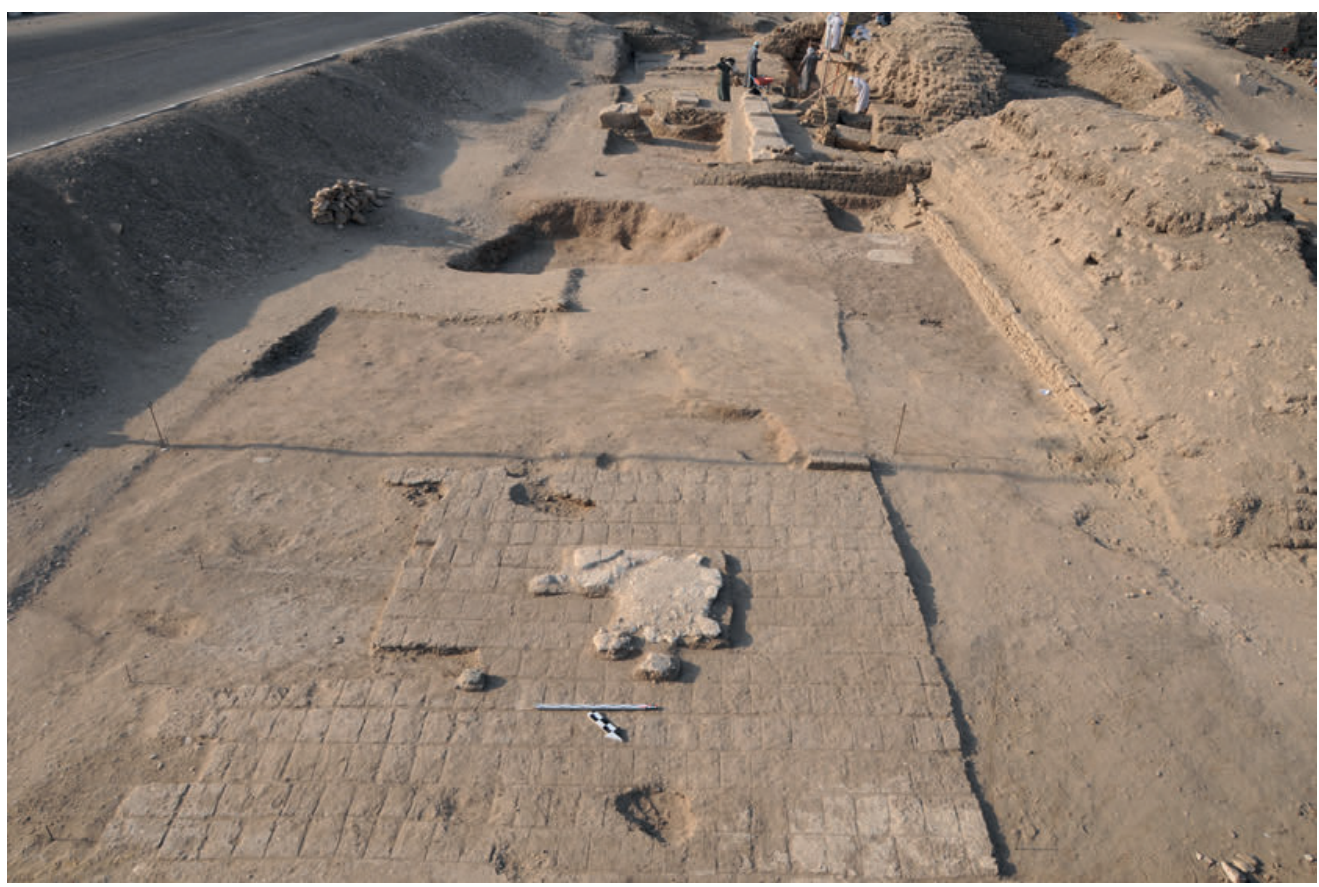

6. Preserved in situ part of the original pavement made of limestone blocks and the mudbrick bedding in the area of the first courtyard (Phot. I. Noureddine (C) Thutmosis III Temple Project).

In front of the central entrance to the second courtyard, some limestone blocks of the original pavement were found in situ. The pavement was founded above a mudbrick platform, which was built of unstamped mudbricks measuring $42 \times 27 \times 9 \mathrm{~cm}$ (Fig. 6).

During the third construction phase, as established already by Ricke, a door was made in the southern section of the original eastern enclosure wall. Remains of a portico with two rows of sandstone pillars were detected along the western limits of courtyard: two bases corresponding to the outer row, and four bases of the inner row were observed in situ. In the north and east, there are traces of mudbrick walls that most likely surrounded this part of the portico.

Next to the outer face of the original enclosure wall two kilns of slaked lime were found. ${ }^{13}$ Both kilns, one found to the south and the other to the north, were detected below the level of the temple floor. They are thus contemporaneous to the construction phase of the temple. In this area the original pavement has not been preserved and for that reason we were able to reach these deeper levels.

\footnotetext{
${ }^{13}$ See: Navarro et al. 2014: 33-35.
} 
In the centre of the second courtyard, the ramp was built to allow access to a higher level (Fig. 5). In the northern part, and very close to the base, there is a preserved alignment of two large sandstone blocks with trimmed ends that probably belonged to the lining of the ramp. Similar but better preserved lining was observed in the ramp leading to the Hathor sanctuary, situated further to the south (see below). To the east of the aforementioned blocks, there is an elongated cut in the bedrock, most probably a foundation trench for further blocks that were, unfortunately, removed at an undetermined moment in the past. In this area, parts of two statues were found (inv. nos 9478, 15442), which will be described below.

In the course of the restoration works the mudbrick core of the ramp has been reconstructed. The ramp was $22.5 \mathrm{~m}$ long and $3.5 \mathrm{~m}$ wide and its angle of incline was $7.5^{\circ}$, with a drop of $3.1 \mathrm{~m}$.

To the north of the ramp three large sandstone blocks are preserved in situ in an alignment parallel to the façade of the terrace. At the north end of this alignment, there is a block of limestone, smaller than the previous ones.

Symmetrically on both sides of a ramp eight tree planters were found (Fig. 7). They were in a better state of preservation than those found by the front of the pylon, ${ }^{14}$ which was due to their localisation on a higher terrace and above the water table. One of them, located south of the ramp, was excavated down to a depth of $8.4 \mathrm{~m}$. This has a diameter of $3.3 \mathrm{~m}$ in the upper part and narrows towards the bottom. Additionally, it is remarkable that the remains of tree roots ${ }^{15}$ and some dry leaves were found inside some tree pits.

In the same area there is some evidence of a mud floor, which would have covered part of the tree planters (Fig. 5).

On the north side of the entrance to the courtyard, and next to the inner face of its eastern enclosure wall, which originally was an outer wall of the complex, a foundation deposit was located (see also below). It was found within the trench prepared for the mudbrick enclosure wall by the lowest course (Fig. 5).

Not far to the north of this deposit, bonded to the enclosure wall, there is a small structure formed by a single row of mudbricks. Two rooms are distinguishable. The entrance is between a curved wall on one side, and a mudbrick platform attached to the enclosure wall on the other. This structure was found below the floor level of the temple, and higher

${ }^{14}$ For the trees distributed around the courtyard, see the Temple of Amenhotep son of Hapu: Robichon, Varille 1936: 27-29, Pls V, XX, XXI; see also: Lipińska 1977: 60-61, 98. For trees in the Lower Courtyard of the Temple of Hatshepsut at Deir el-Bahari, see: Arnold 1975: 1014, 1019 [6], Fig. 1 [11]; 1979: Pl. 44; Winlock 1932: Fig. 1.

15 The remains of tree roots present different shapes, but their anatomy is consistent with the characteristic of the genre Mimosups sp, according to the analysis of R. Piqué. 


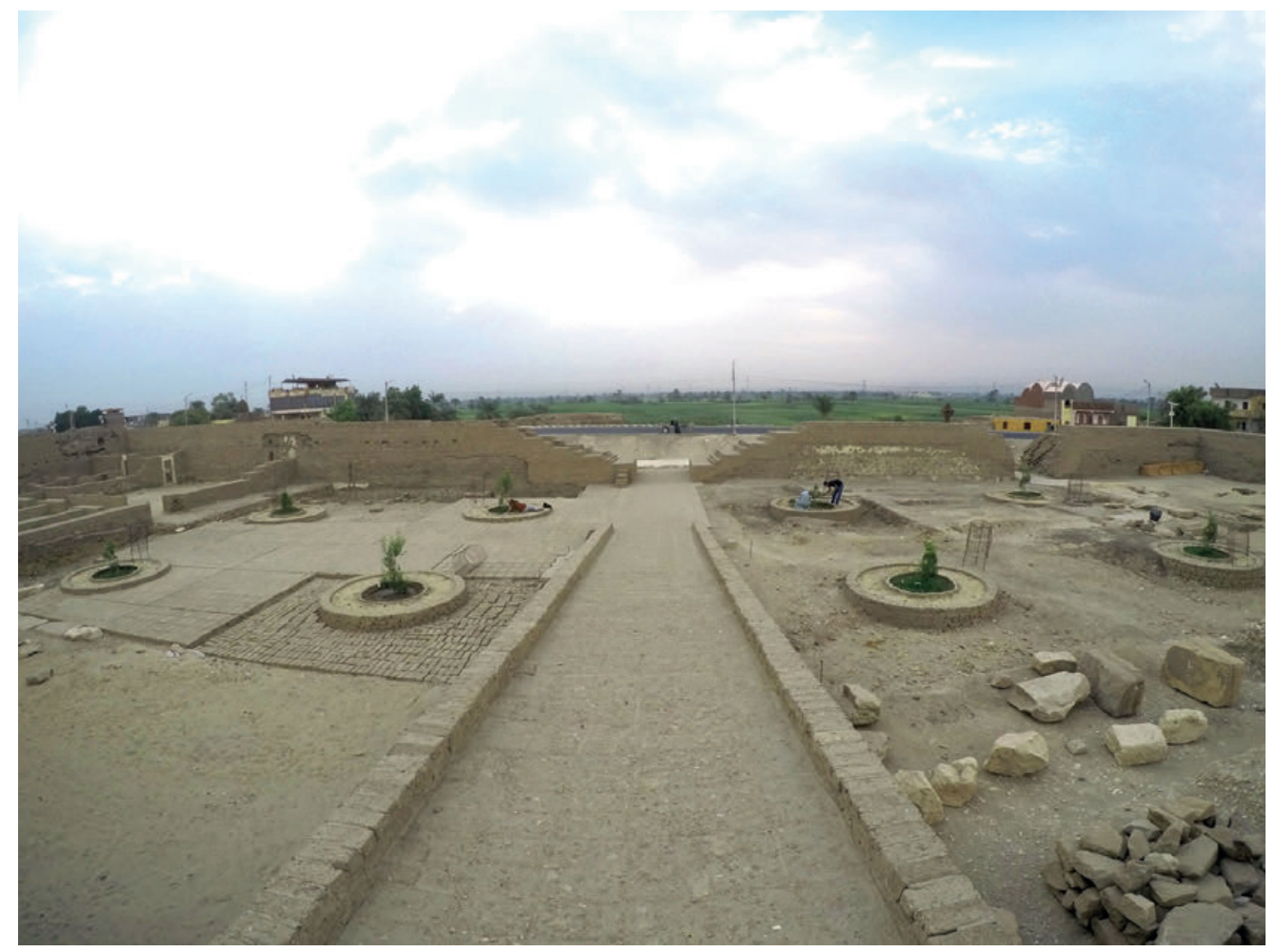

7. Tree pits in the area of the second courtyard (Phot. M. Seco Álvarez (C) Thutmosis III Temple Project).

than the foundation deposit with no direct relation to it. The structure could be associated with the building process of the temple (Fig. 5). ${ }^{16}$

In the southern part of the courtyard, it was possible to identify a pavement of mudbricks that extends $5.25 \mathrm{~m}$ starting from the eastern enclosure wall (Fig. 5). A well visible row of mudbricks delimits the pavement on the west. Beyond this line there is evidence of a compacted mud floor levelling the irregularities of the bedrock.

In the south-western part of the courtyard, a north-south cut of the bedrock can be distinguished, parallel to the terrace façade. Perhaps it is connected to the aforementioned alignment of sandstone blocks in the north-western part of the courtyard, located symmetrically on the other side of the ramp (Fig. 5).

South of the courtyard, in an area close to the southern enclosure wall, important structures were erected during the period defined by Ricke as the third phase of construction.

${ }^{16}$ Artifacts, such as bases of Eighteenth Dynasty beer vessels, were reused as containers for gypsum/mortar. Its remains bear finger marks indicating its usage in building process. The presence of vessels with such contents beneath the floor of the temple indicates their application to level the floor after the completion of the construction. The above-mentioned pottery was studied by M. Naguib Reda and M. El-Shafai. 


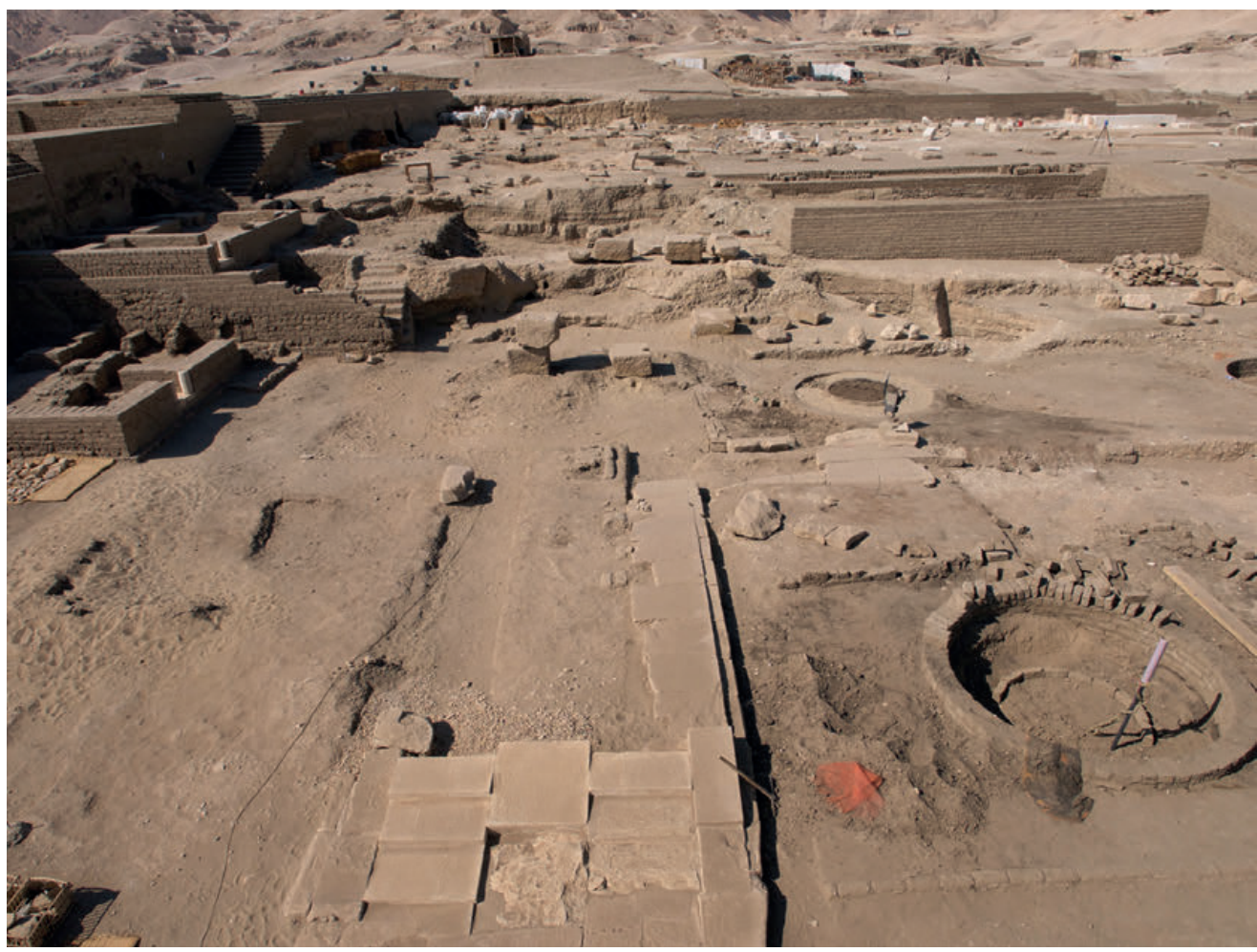

8. Southern ramp leading to a sanctuary dedicated to Hathor (Phot. M. Seco Álvarez $\odot$ Thutmosis III Temple Project).

The first of them is a ramp, unfortunately very much damaged (Fig. 8), leading to a sanctuary dedicated to Hathor. The ramp was composed of a mudbrick core and some sandstone as well as undecorated limestone blocks (Fig. 5). In fact, in the northern section of the ramp there is an alignment of thirteen large sandstone blocks, which have irregular edges. In the southern section three other blocks are visible, which were likely part of the stone casing. Some limestone blocks are also preserved at the beginning of the ramp: they are inclined, plane, ascending in the centre, flanked by stairs on each side, with steps $1.08 \mathrm{~m}$ wide. In addition, at the western almost completely destroyed end of the ramp, we can still see some sandstone foundation blocks: two overlapping on the southern side and one to the northern. These were probably part of the stone footing that supported the stone casing of the ramp itself. Among these blocks there are still some mudbricks from the ramp's core.

Perpendicular to the ramp, on its northern side, a long trench was cut into the bedrock, in which sandstone blocks were probably originally fitted. Three blocks are preserved at the southern end of the trench. On these three blocks, there are builders' guidelines, separated $1.56 \mathrm{~m}$ from each other, indicating the position of two pillars. A third one was bonded to the ramp, and only a small mark of it remains on the ground (Fig. 5). 


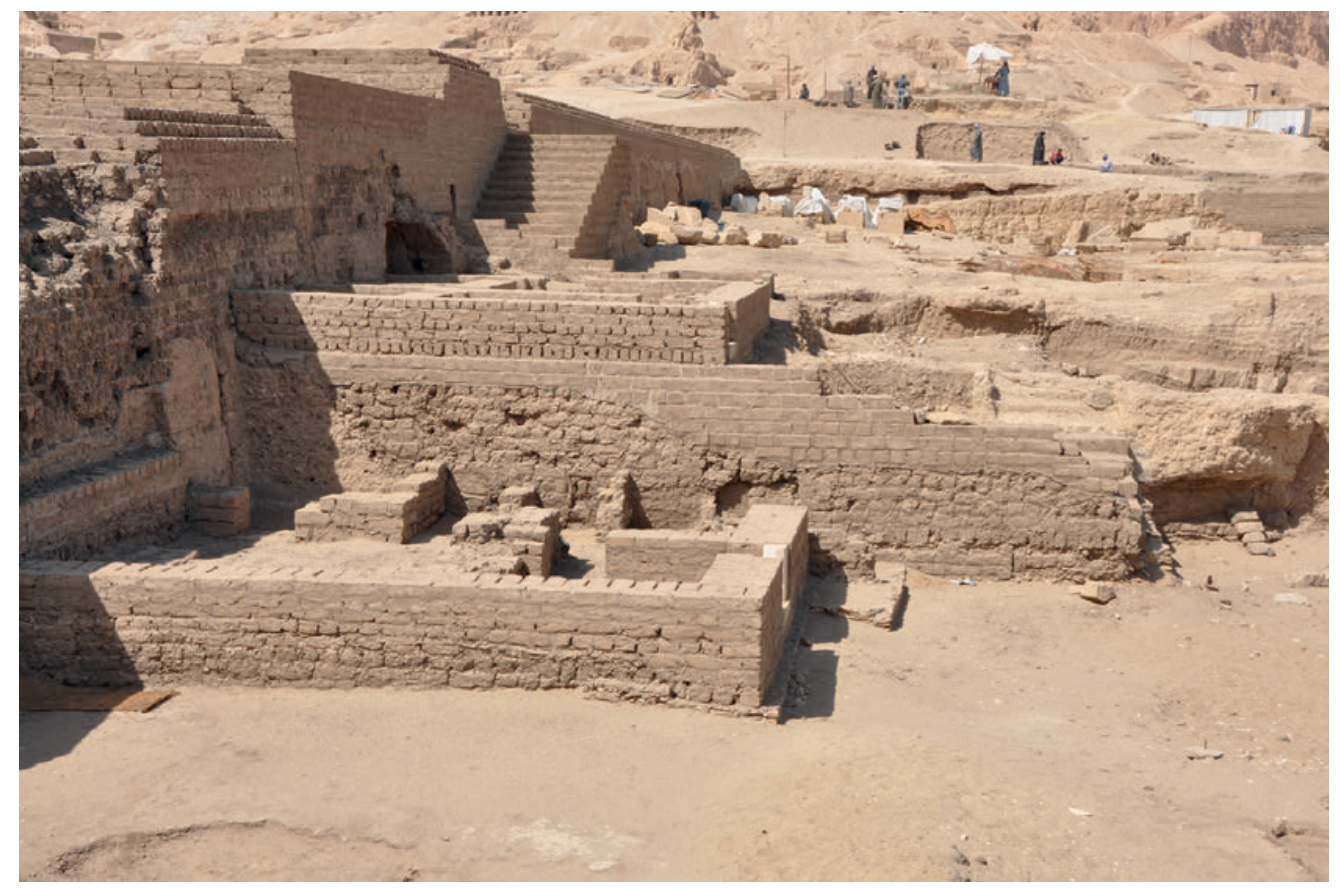

9. Mudbricks buildings south of the second courtyard (Phot. M. Seco Álvarez (C Thutmosis III Temple Project).

South of the courtyard, in the southeast corner of enclosed area are some mudbrick walls of small buildings. Moreover, near the southern end of the aforementioned southern ramp, there is a L-shaped mudbrick construction. Finally, in the western corner of the enclosed area, a multi-room building was documented, which, according to the Ricke, is dated to the Ramesside period (Fig. 9). ${ }^{17}$

North of the courtyard was a complex of warehouses, partially modified after the reign of Thutmose III (Fig. 10). The only remains from the time of this great pharaoh is a wall with a similar orientation to the façade of the enclosure wall, and with - in its central section - a mudbrick staircase, leading to an upper storey, which is no longer preserved. In a subsequent phase, which can be dated to the end of the Eighteenth Dynasty, the staircase became unusable.

The discussed architectural complex had an entrance in the middle of southern wall. It lead to a corridor, $15.50 \mathrm{~m}$ long and $2.75 \mathrm{~m}$ wide, which separated the complex into two groups of rooms. In the west, there were five rectangular rooms, while in the east, according

17 This area was not excavated by Daressy but only by Weigall in 1906 and by Ricke in the 1930s; see: Ricke 1938: P1. 4. The area on the other, southern side of the enclosure wall was not researched by any of our predecessors, since they made dumps there. Some sizeable mudbrick structures with wide walls were found there (see also below), which are still under investigations. 


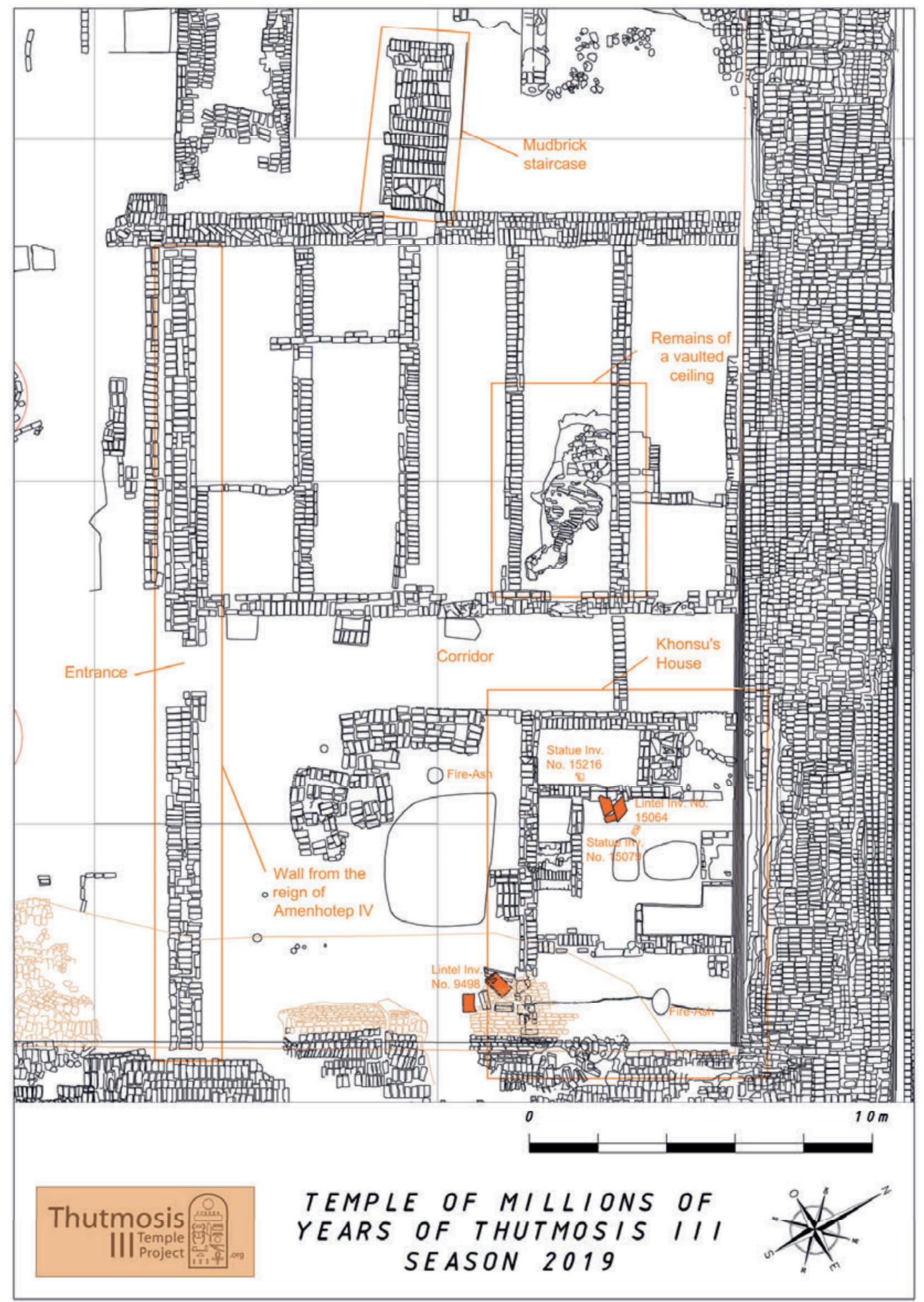

10. Area of warehouses to the North of the second courtyard (Surveyor: J. Tre García; drawing: E. Úbeda (C) Thutmosis III Temple Project). 
to Ricke, there were many others. ${ }^{18}$ The rooms in the western sector are $10.20 \mathrm{~m}$ long. The three from the centre are $2.60 \mathrm{~m}$ wide and the other two $2.80 \mathrm{~m}$ wide. Little from this western part is preserved. All the rooms have entrances from the east and in one of them part of a vaulted ceiling fallen to the ground was found (Fig. 10).

From the reign of Amenhotep IV, only part of a southern outer wall of the complex, perpendicular to the eastern enclosure wall, is preserved; the date of this structure is corroborated by some stamped mudbricks of this ruler.

Archaeologists ${ }^{19}$ working earlier at the site were unable to finish excavation of this complex since it was covered by the fallen enclosure wall, which collapsed when all the courses of the mudbricks enclosure wall fell together during a severe earthquake. However, after removing the debris from this wall, it was possible to excavate an entire new area that had never been exposed before, and above all the house of Khonsu, the first priest of this temple in the time of Ramesses II (Fig. 10) ${ }^{20}$

During the 2013 season, the area of the old research was cleaned and new excavation started yielding a mudbrick building comprised of several rooms (Fig. 11). This building (Fig. 10) has an entrance in the south, where the remains of two limestone jambs and a limestone lintel were found. This entrance leads to a rectangular room which gave access to a central room, located further to the west. To the south of this room, there was a staircase of which only some steps made of mudbricks are still visible. This most probably gave access to the upper floor of the building. In the western part were smaller rooms attached of which the southernmost contained several broken sandstone fragments of a lintel. In the room located to the north some mud bricks stamped with the cartouche of the throne name of Ramesses II were found: $\left(W s r-m_{3}{ }^{\prime} t-R^{\prime} s t p-n-R^{\prime}\right) \mid$. In the western part of the room, there was another door that probably led to the warehouses that were still standing then.

Archaeological works in this area brought finds of great significance, among which one should highlight in particular the door jambs in limestone and two very interesting and beautiful lintels, one in limestone (inv. no. 9498) and another in sandstone (inv. no. 15064). Both contain similar scenes in which a high priest, Khonsu, is worshiping the cartouches of Thutmose III (see below). Near the aforementioned lintels, two lower parts of seated statues (inv. nos 15079 and 15216) were found (see below). ${ }^{21}$

${ }_{18}$ Ricke 1938: 16-17, Pls 5-6.

19 Weigall 1907: 286; Ricke 1938: 16-17 and Pl. 4.

${ }^{20}$ The date of this complex and the fact that all the portable finds found below the collapsed wall are of Ramesside period allows us to date the earthquake to the time of Ramesses II or later in this period. For other evidence of the earthquakes which have taken place in the region, see: Karakhanyan, Avagyan 2010: 264 270; Sourouzian 2011 et al.; Karakhanyan, Avagyan, Stadelmann 2014; Stadelmann 2014; Sourouzian 2014; Karakhanyan et al. 2014; Lurson 2017.

${ }^{21}$ Seco Álvarez, Martínez Babón 2015a: 383-391, Pls 47-52. 


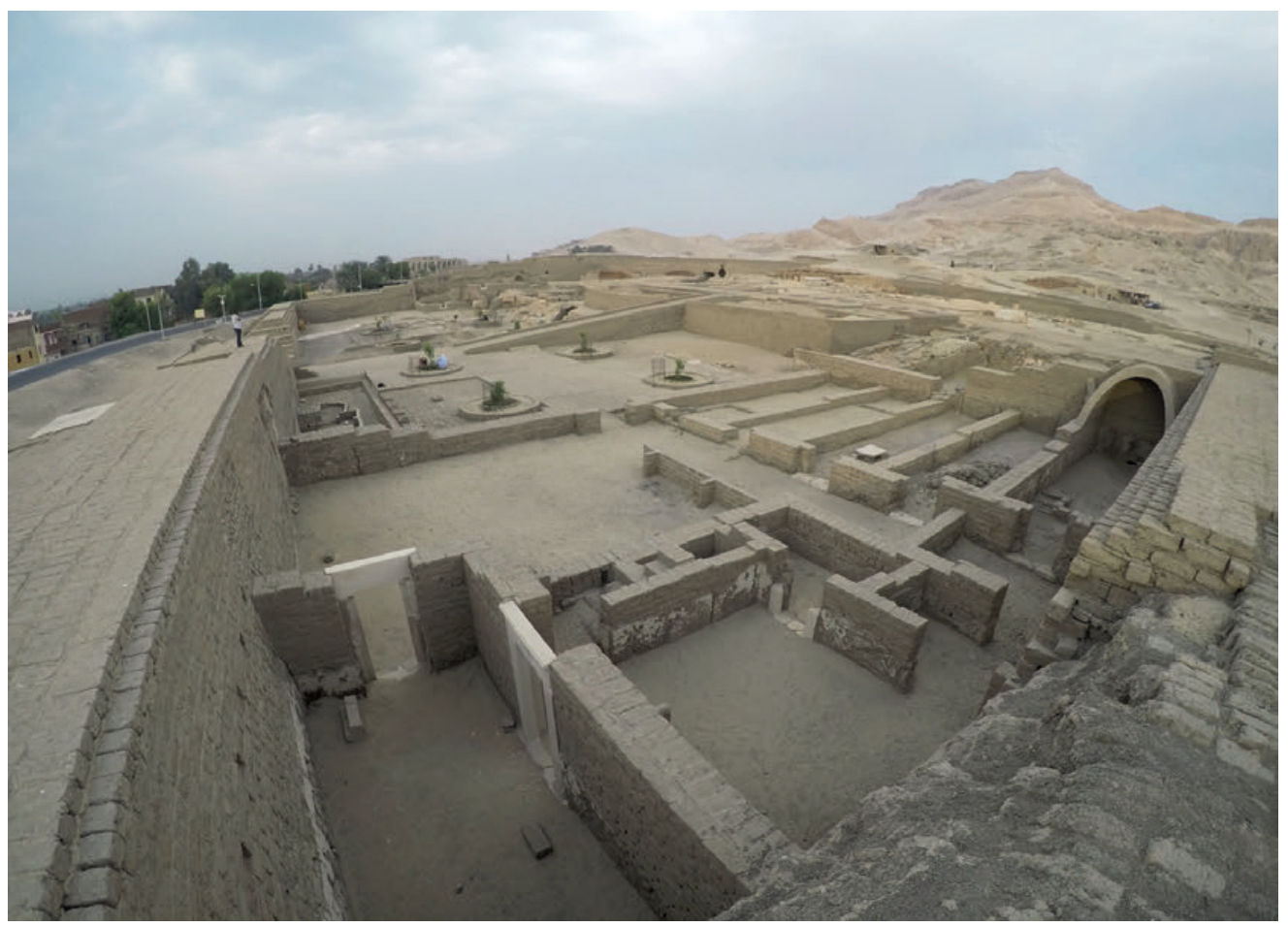

11. Mudbricks buildings to the North of the second courtyard (Phot. I. García Martínez (C) Thutmosis III Temple Project).

\section{UPPER TERRACE}

The upper terrace consisted, from east to west, of a portico, peristyle, hypostyle hall and chapel area, ${ }^{22}$ all of them surrounded by a wall built of large sandstone blocks (Fig. 12). The enclosed area measured $33.46 \mathrm{~m}$ by $50.7 \mathrm{~m}$, what can be reconstructed on the basis of the negatives of the wall preserved on some of the pavement blocks that are still in situ.

Due to the high level of destruction, which hinders any attempt to study the original architecture of the temple, Ricke raised various hypotheses about the structures that were once located on this terrace. Thus, he presented plans with different possibilities of the configuration of the portico, the peristyle and the hypostyle rooms. ${ }^{23}$ The following is a description of the remains that are currently visible in this part of the temple.

Only two rectangular sandstone bases are preserved from the portico. The cuts on their upper part allow us to suppose that above them were large Osiride statues with their characteristic back pillars. ${ }^{24}$

\footnotetext{
22 Ricke 1938: 9-15.

23 Ricke 1938: Pls 5-6.

24 Ricke 1938: 10. However, we have not found evidence of Osiride statues.
} 


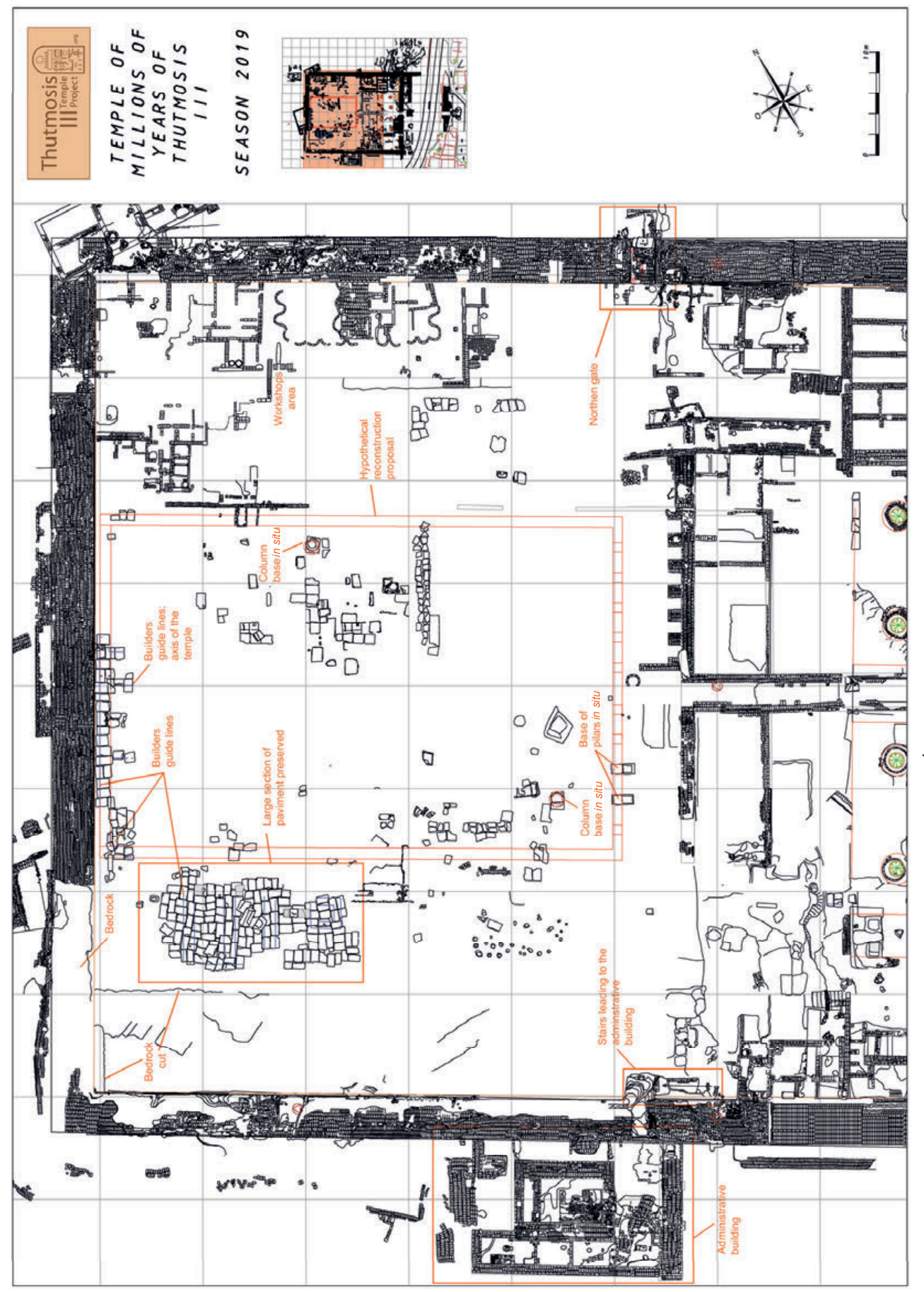

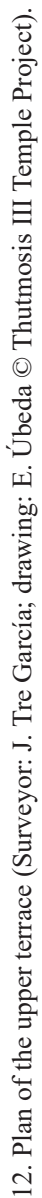



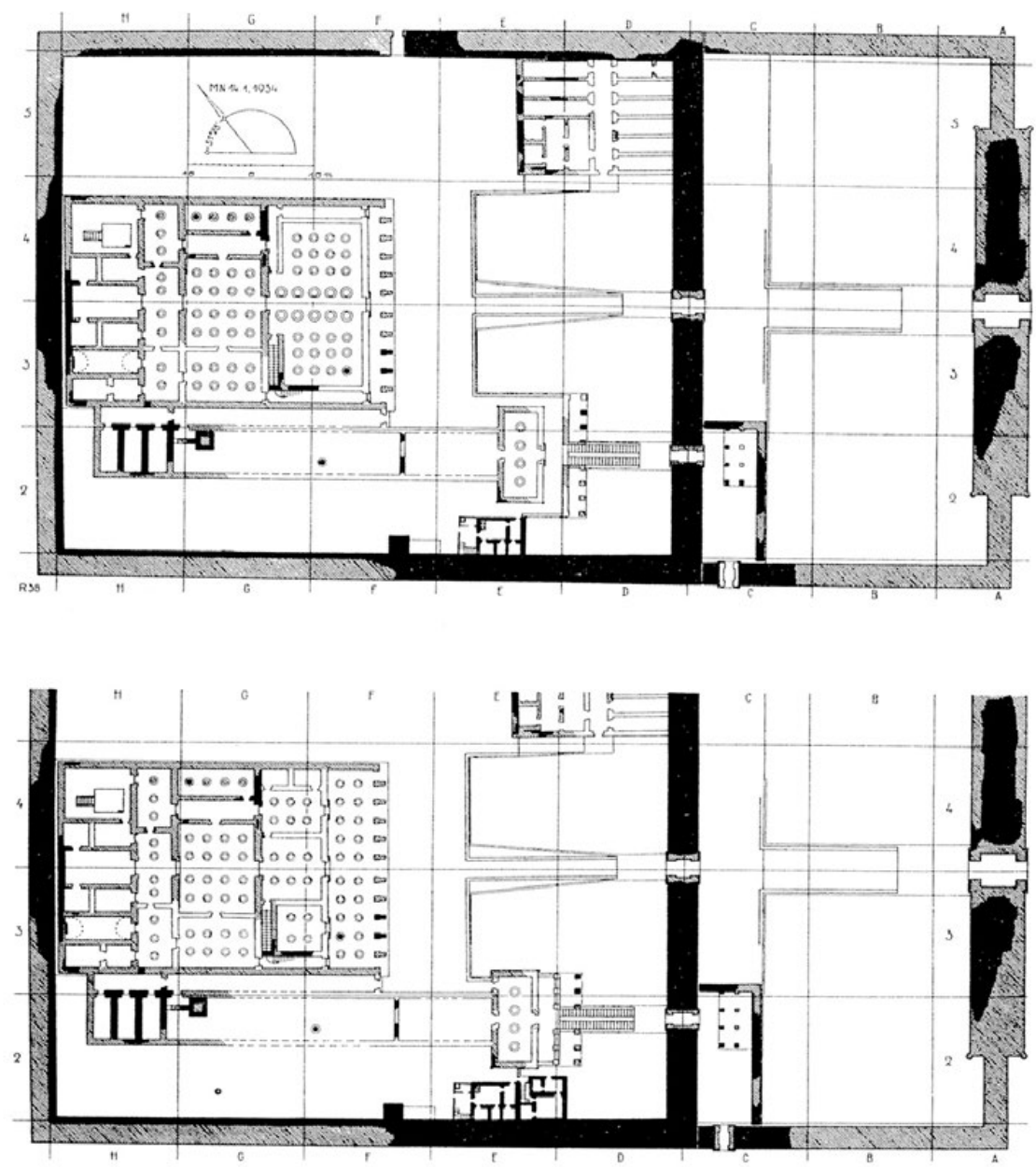

13. Possible hypothetical reconstructions of the temple, as proposed by Herbert Ricke: B (top) and C (bottom) (Ricke 1938: Pl. 6).

To the west of the portico, there is a sandstone column base, near which are some slabs of the original sandstone pavement in place. Due the lack of architectural remains, it is not certain whether this column was part of the peristyle or of a double portico. Ricke proposes several hypotheses in this matter (Fig. 13). ${ }^{25}$ The preserved slabs create an alignment, oriented east-west. About $14 \mathrm{~m}$ north of these slabs, there are remains of a wall of large limestone blocks, which is oriented north-south, and parallel to the portico. In this wall, there is evidence of a doorway that led to some rooms to the west, of which an entrance to

25 Ricke 1938: 10, Pl. 6. 


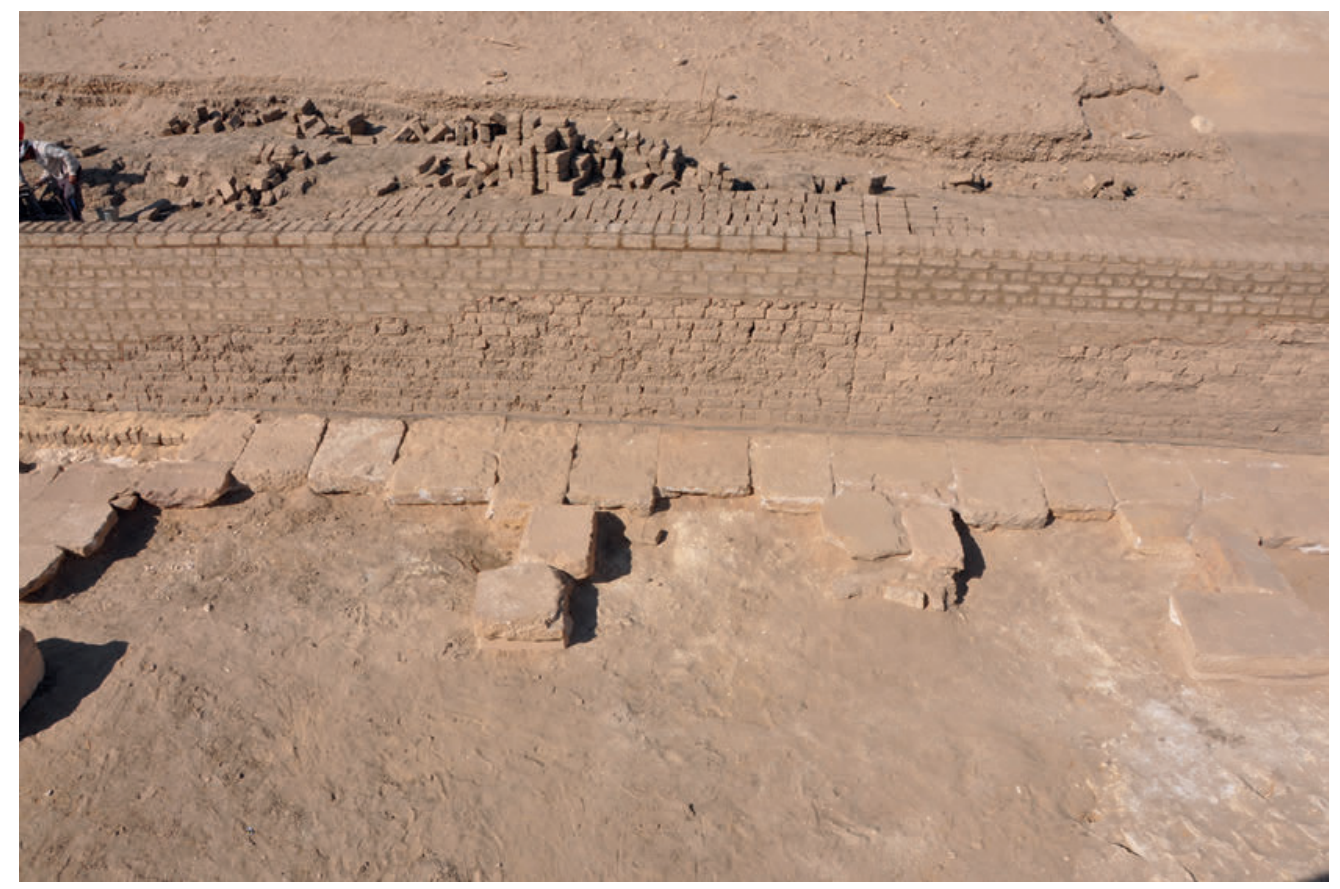

14. Area of the main sanctuary, upper terrace (Phot. M. Seco Álvarez (C) Thutmosis III Temple Project).

the north and a column base to the west are preserved. This column base probably belongs to one of the rooms of the hypostyle hall (Fig. 12).

Traces of pavement formed by large sandstone slabs are visible in various parts of this area. Some of those slabs, adjacent to the western enclosure wall, are crucial for the temple layout reconstruction. On two of them, the mark that indicated the axis of the temple can be identified (Fig. 14). Detailed analysis of these slabs also allows us to reconstruct the position of chapels, which are, unfortunately, not preserved.

In Ricke's opinion, there were five chapels and a solar court in this part of the temple (Fig. 13). The central one would correspond to Amun-Re's Bark Hall. Large blocks of limestone with iconography and inscriptions related to this god could come from this chapel. ${ }^{26}$ Most of them, along with many others in sandstone, were located in a shack, built by Weigall, inside the temple and next to the western enclosure wall. This shack was also used by Ricke to store his finds. Over time, these materials were forgotten and covered by sand and they were found by the Spanish team during 2008 field season. Additionally, other blocks were scattered over the western part of the temple.

Ricke indicated that in the northern corner of the terrace there was a courtyard dedicated to the solar cult, very similar to that preserved in the temple at Deir

${ }^{26}$ Seco Álvarez, Martínez Babón 2015c: 525-536. 
el-Bahari. ${ }^{27} \mathrm{He}$ noted the remains of an altar, already mentioned by Weigall, ${ }^{28}$ of which there is currently no evidence.

A chapel dedicated to the funeral cult of Thutmose III must have been located to the south of the Amun-Re's Bark Hall. Here large sandstone blocks were recorded of the form suggesting that they originally formed the vault characteristic for chapels of the funeral cult. The blocks were decorated with representations of goddesses of the hours of day and night, as well as with inscriptions in yellow on blue background. Analysis of the section through the western pavement of the funerary chapel indicates where the great false door stele of Thutmose III, which was moved in Roman times to Medinet Habu, would have originally been. ${ }^{29}$ The false door is decorated with the remains of the feet of the personifications of the Twelfth Hour of the Day (south) and the First Hour of the Night (north).

The southernmost chapel could have housed the cult of the ancestors of Thutmose III, similar as in the Temple of Millions of Years of Hatshepsut at Deir el-Bahari. ${ }^{30}$

To the south of the aforementioned complex of five sanctuaries and the solar court, a large section of pavement is preserved. The negatives of the walls are visible on slabs, probably corresponding to a complex of three chapels with the entrances located to the north (Fig. 12). According to Ricke, one could enter them through a long corridor, which was accessed by the portico, located in the southern corner of the second courtyard. Unfortunately, the evidence is too scant to confirm this hypothesis.

In Ricke's opinion, the aforementioned changes in the area of the second courtyard related to the third construction phase, i.e. the opening of an entrance in the southern part of the eastern enclosure wall and the raising of a southern ramp, were connected with the construction of a sanctuary dedicated to the goddess Hathor. Ricke's interpretation was based on the southern position of the sanctuary, similar to the placement of the Hathor chapel in Hatshepsut's temple and on the discovery of a Hathoric capital that was published and illustrated. ${ }^{31}$ This hypothesis is also corroborated by the attestation of a priest named $\mathrm{Re},{ }^{32}$ who held the rank of First Prophet of Hathor in the middle of the Henket-ankh (hm-ntr tpy $n H w t-H r h r t-i b H n k t-' n h$ ) in an inscription from his tomb (TT 72). ${ }^{33}$ According to Ricke, the entrance to this sanctuary was composed of a portico formed by pillars with Hathoric capitals. ${ }^{34}$

Currently, the state of preservation of this area does not allow us to reconstruct its detailed plan, although Ricke suggested the existence of at least one niche here. ${ }^{35}$ Nonetheless,

${ }^{27}$ Ricke 1938: 12; Karkowski 2003.

${ }^{28}$ Weigall 1906: 123.

${ }^{29}$ Ricke 1938: Pl. 8.

${ }^{30}$ Ricke 1938: 10-11, 30-32; Chapon 2018b: 57; see also: Naville 1901; 1906; Iwaszczuk 2016a: 112-116; 2016b: 202-221.

${ }_{31}$ Ricke 1938: 28-30, Pl. 3; for a more detailed study, see: Chapon 2020, especially p. 52, n. 69.

32 Seco Álvarez, Martínez Babón 2015b: 129-135.

${ }_{33}$ PM I.1 $1^{2}, 142-143$.

${ }^{34}$ Ricke 1938: 21, 25, Pl. 3c. For further interpretations in this respect, see: Chapon 2020.

${ }^{35}$ See: Ricke 1938: Pl. 3d; fragment of block published by Ricke as coming from here. 
a series of cuts in the bedrock probably mark where the chapel was situated, although it is no longer preserved.

In the southern corner of the upper terrace, stairs attached to the enclosure wall were recorded, which gave access to the top of the wall (Fig. 12). Excavations carried out down to the bedrock in the area, but outside the enclosure wall, allowed the mission to discover where they originally led. A mudbrick building, $20 \mathrm{~m}$ long and $13 \mathrm{~m}$ wide, was found there. It consisted of a hall that allowed access to a main room with thick walls and a vaulted ceiling, now collapsed, surrounded on the south and north by a series of rooms. The threshold of the entrance door to the hall consisted of a long and thick piece of wood. Although the vaulted ceiling suggests a storage function, numerous ostraca found in this area allow us to propose that it was an administrative building.

In the northern sector of the upper terrace, between the northern stone wall of the temple and the northern mudbrick enclosure wall, a series of quite uniform mudbrick buildings was found. These could be remains of artisan workshops, according to some preliminary analysis. ${ }^{36}$ While this area is still under archaeological excavations, it can already be noted that it encompasses numerous rooms built with simple walls, some in an irregular zigzaglike manner, with mudbrick and clay floors (Fig. 15). It should also be noted that many of these rooms were directly attached to the enclosure wall. Stratigraphy allowed the team to determine at least three phases of activity in this area.

A first phase was most likely related to the early history of the temple. It seems that activities related to clay were carried out then in this area, since a large amount of this material was found there. In the second phase there was clearly a need to create a larger working space. The previous floors were changed and filled in with limestone, sandstone and sometimes ceramic chips. This phase is related to increased activity in the temple and the demand for a larger number of rooms for an increased amount of work. Finally, the third phase is characterised by the construction of a larger number of smaller rooms.

In this area mostly pottery was found, some ostraca and papyri fragments, but also a large quantity of animal coprolites. This may indicate that cattle was kept in this area. Likewise, small plastered structures, some with ash spot and small ovens, suggest that food was also prepared here. ${ }^{37}$

The area of the northern enclosure wall was remodelled in a later phase. In the spot aligned with the portico of the temple, an entrance was opened (Fig. 12). A short mudbrick ramp was located there. Traces of a sandstone threshold and limestone jambs have also been

36 This area was excavated by Daressy in 1886, and he had made a first plan of this sector; see: Daressy 1926: 14-15 (n. 3) and 16 (plan). It was also excavated by Weigall in 1906; see plan in: Weigall 1907: 286. Nevertheless, Ricke did not utilise these plans when preparing his hypothetical reconstruction of the temple.

37 This area is currently under excavation and the results of this investigations will be published in the future. 


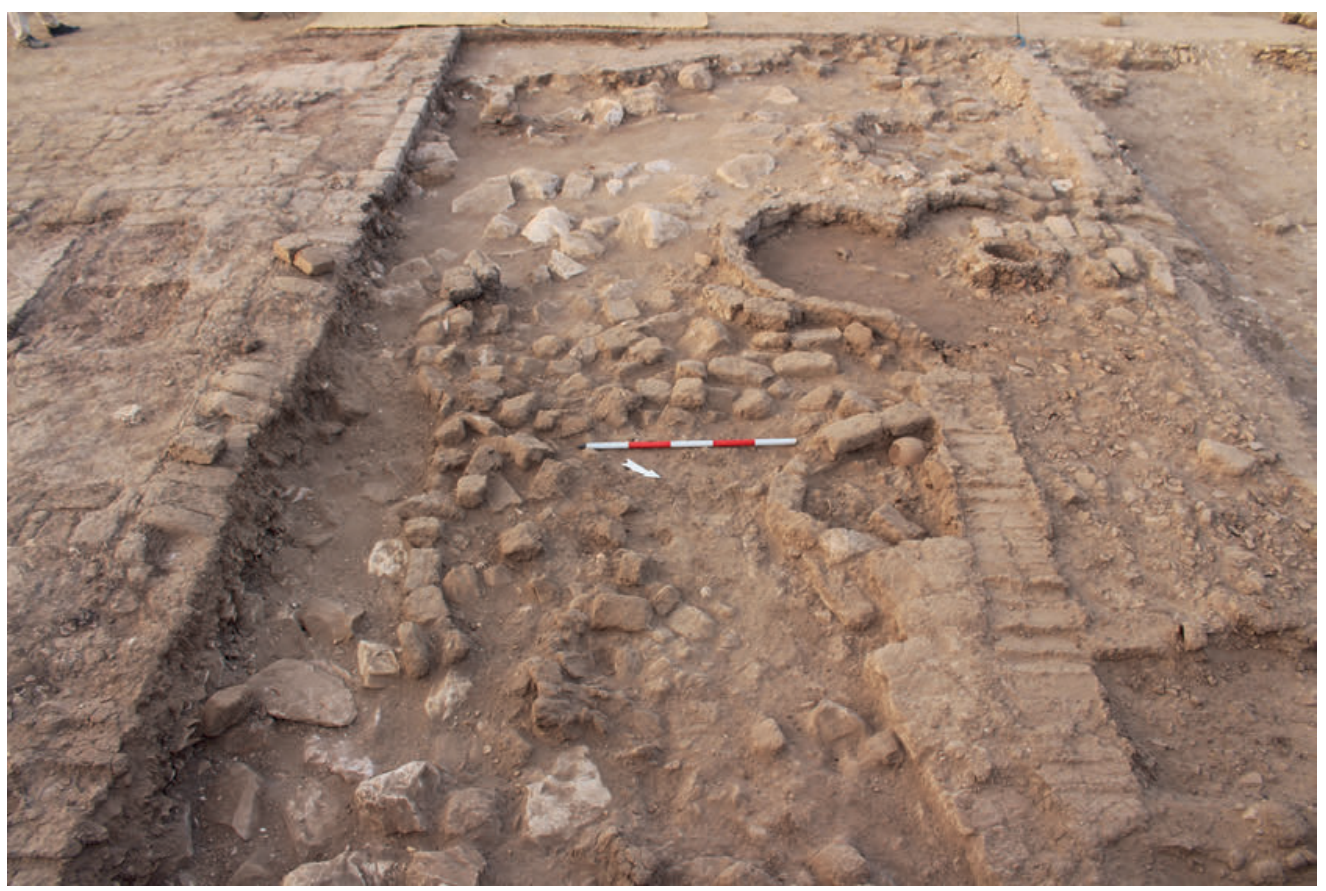

15. Workshop area in the northern part of the upper terrace (Phot. I. Delague (C) Thutmosis III Temple Project).

preserved. Unfortunately, the chronology of this remodelling cannot be determined, although it was observed that at some point this door was walled up again and the inner chamber of the gate was used as a storage room, as demonstrated by the presence of a mudbrick floor and two ceramic containers.

Discarded pottery, stoppers, broken stelae and small papyri fragments from the temple were thrown outside the northern enclosure wall, when the temple was in use, so that a dump grew there to a size of approximately $750 \mathrm{~m}^{2}$, reaching almost $3 \mathrm{~m}$ deep in some parts. ${ }^{38}$ However, the topmost layers of the dump contain some material discarded during earlier excavations at the site.

\section{FINDS}

The twelve excavation campaigns that have been carried out to date have made it possible to recover numerous objects related to the temple. The following sections will, however, only present some of the most significant finds. Other, not discussed below, categories include large amounts of pottery, complete vessels among others, numerous fragments of

${ }^{38}$ See: Bader, Seco Álvarez 2016: 157-262. Between 2008 and 2014 the pottery was studied by B. Bader and from 2014 by M. Naguib Reda and M. El-Shafai. 
terracotta votive figurines, tools of different materials and small finds of different function, scarabs among other things. ${ }^{39}$

\section{SANDSTONE AND LIMESTONE RELIEFS}

During the first field season in 2008, a large deposit of sandstone and limestone fragments attached to the western enclosure wall of the temple was found. These were objects stored here by Weigall, and the same space was later used by Ricke for his finds. The deposit contained hundreds of large limestone blocks with reliefs and inscriptions and thousands of very small fragments. It is significant that most of them relate to the figures of the pharaoh and the god Amun-Re, as well as to this god's bark and offering tables. This observation allowed the members of the mission to conclude that these blocks were likely part of the walls of the chapel of this deity. ${ }^{40}$ They clearly illustrate the persecution against Amun during Akhenaten's reign: the figure of the god, attributes and name were thoroughly erased (Fig. 16). ${ }^{41}$

Moreover, about 9,000 sandstone fragments of different sizes have been found in other parts of the temple. ${ }^{42}$ Most of them are in a poor state of preservation, but some have extraordinary polychrome decoration. They provide important information on the decorative design of the walls of the temple. Along with evidence of a religious nature, such as priests performing rituals, offering bearers or offering lists with the pharaoh and some divinities as the protagonists, especially Amun-Re, interesting fragments of reliefs relate to the Pharaoh's sed-festival and ished-tree (inv. nos 726, 893, 930, 965, 999, 1049, 1232, and 1758). ${ }^{43}$

Other sandstone fragments from the vault were decorated with the Ritual of the Hours, which was first attested in the Temple of Millions of Years of Hatshepsut at Deir el-Bahari. ${ }^{44}$ The text is divided into twenty-four hours, twelve for the Day and twelve for the Night. It was accompanied by an image of the personification of each hour standing in front of Thutmose III. Many of these fragments were previously published by Ricke, who noted that they were originally part of the vaulted room just to the south of the temple sanctuary. ${ }^{45}$

Some fragments preserve inscriptions and representations related to military campaigns and triumphs over foreign territories, military parades and navigation scenes. For example, part of a chariot and the hind legs of horses can be seen on a relief that preserves good polychrome (inv. no. 9471); the incomplete image of a rider, which would be one of the

39 See: Franco González 2019.

40 Since 2019, K. Griffin is working on this material.

${ }^{41}$ Seco Álvarez, Martínez Babón 2015c: 525-536.

42 See: Martínez Babón 2015: 248-263; Chapon 2018 b.

${ }^{43}$ Chapon 2016: 47-56; 2018a: 123-143.

${ }^{44}$ See: Griffin 2017: 97-134, which contains an overview of all the known sources (at the time of writing) related to the subject, including Deir el-Bahari and the discussed Thutmose III temple.

${ }^{45}$ Ricke 1938: 11-13, Pls 1-2. In 2019, K. Griffin started work on an article dealing with the fragments related to Ritual of the Hours coming from the temple. 
16. Limestone blocks with relief decoration: a. inv. no. 5109; b. inv. no. 5893

(Drawing: E. Kamimura C Thutmosis III Temple Project).

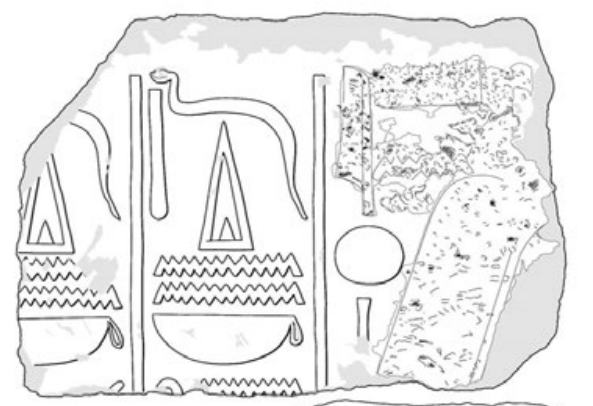

a
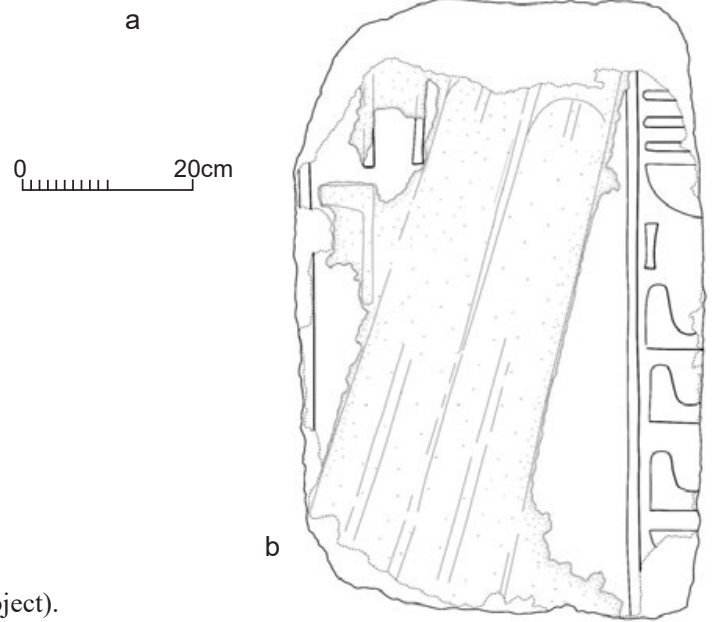

oldest Egyptian representations of a man mounting a horse (inv. no. 678); an Asiatic fortress painted in red, of a characteristic form of a migdol (inv. no. 1455) or the lower part of a rowing boat and the heads of two horses in the same relief that could be related to some kind of amphibious operation (Fig. 17). In this context, we should keep in mind that the Annals of this pharaoh, which are known from Karnak, are devoid of iconographic elements. Unfortunately, the inscriptions from the Henket-ankh are very badly preserved. One of most interesting fragments mentions an elephant hunt in the Syrian land of Niya (inv. no. 3251). ${ }^{46}$

It should also be noted that some sandstone fragments preserve the names of different members of the royal family, such as Thutmose I, Thutmose II, Hatshepsut and Amenhotep II, ${ }^{47}$ as well as the queens Mutnefer or Merytre Hatshepsut. ${ }^{48}$

${ }^{46}$ Martínez Babón 2015: 253-254; Chapon 2018b: 303.

${ }^{47}$ Martínez Babón 2015: 258-260; Chapon 2018b: 134-146; Seco Álvarez, Martínez Babón 2019: 131-139, Pl. XVII.

${ }^{48}$ Chapon 2018a: 123-143. 


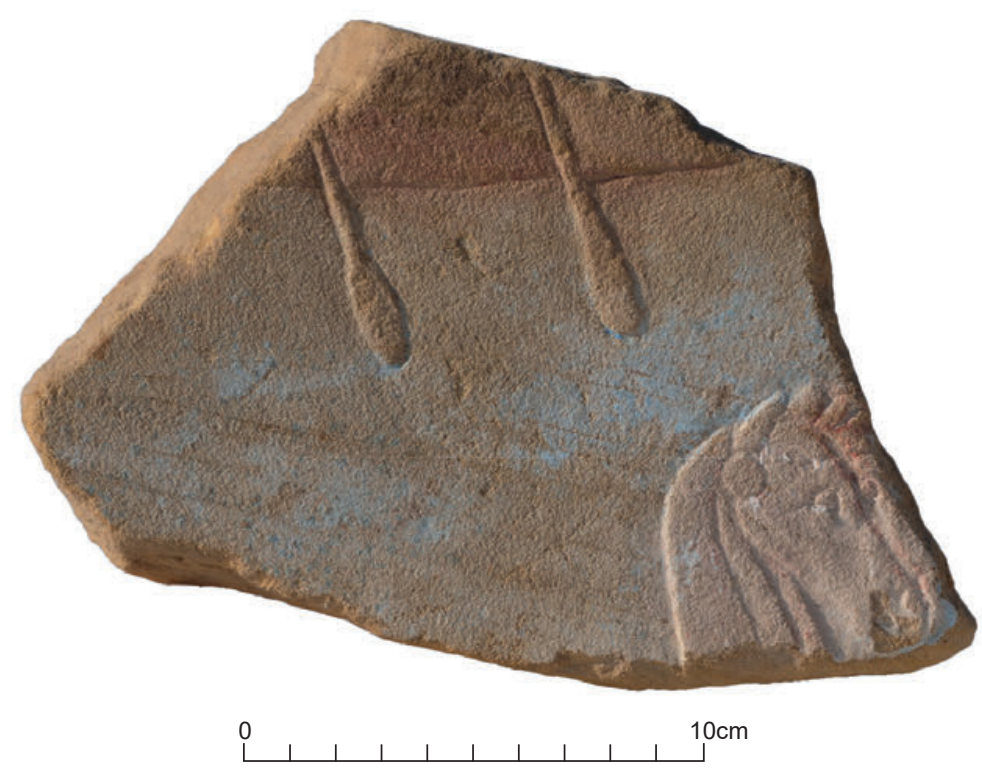

17. Exemplary sandstone fragment with relief decoration, inv. no. 9112 (Phot. A. Amin (C) Thutmosis III Temple Project).

\section{LINTELS FROM THE KHONSU COMPLEX}

Of particular importance are the two lintels from the house of the high priest named Khonsu (Fig. 10). The first one, made of limestone ( $42 \mathrm{~cm}$ high, $134.5 \mathrm{~cm}$ wide and $15 \mathrm{~cm}$ deep) is decorated with the two cartouches of Thutmose III in its central part (Fig. 18). They were placed vertically, over the $n b w$-sign and crowned by the $p t$-sign. These cartouches contain the following names: Djehuty-mes and Men-kheper-re-setep-en-re. ${ }^{49} \mathrm{On}$ both sides of the cartouches, there are two practically identical figures of a priest Khonsu raising his arms in a gesture of worship. The priest is represented with a shaved head, attire that is characteristic of the Ramesside era, ${ }^{50}$ and sandals. ${ }^{51}$ Between the cartouches and the figures of Khonsu, there are two similar inscription, written in two columns (from left to right): $h m-n \underline{t} r$ tpy $n(M n-h p r-R) \mid$ Hnsw m3 'hrw ms T3-wsrt, 'First god's servant of (Menkheperre)|, Khonsu, justified, born of Tausret'.

The central part of the second, sandstone, lintel $(40 \mathrm{~cm}$ high, $136.5 \mathrm{~cm}$ wide and $14 \mathrm{~cm}$ deep) bears the same cartouches of Thutmose III, placed vertically over the $n b w$-sign and crowned by a solar disc (Fig. 19). The gesture of the priest and the inscription are similar

49 This form of the throne name is preserved in sources dated after year 20 of the reign of Thutmose III: Laboury 1998: 64, nos 334 and 68.

50 Zoffili 1992: 95; Vogelsang-Eastwood 1992: 17-18.

51 Zoffili 1992: 217; Gamal-Eldine 1981. 


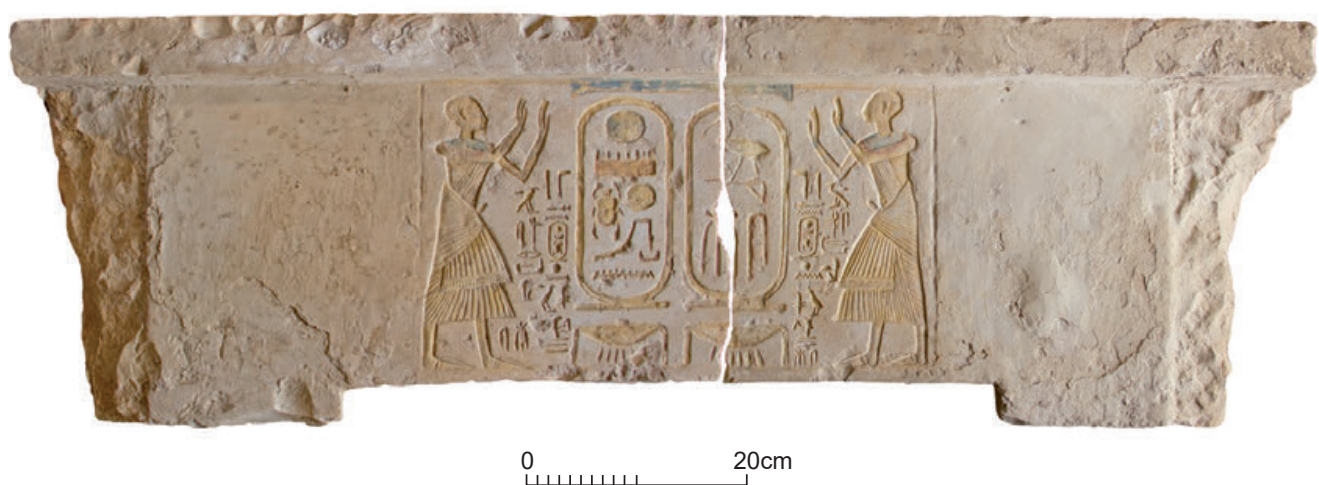

18. Limestone lintel of Khonsu; inv. nos 9498B and 9498A, from left to right (Phot. M. González Bustos (C) Thutmosis III Temple Project).

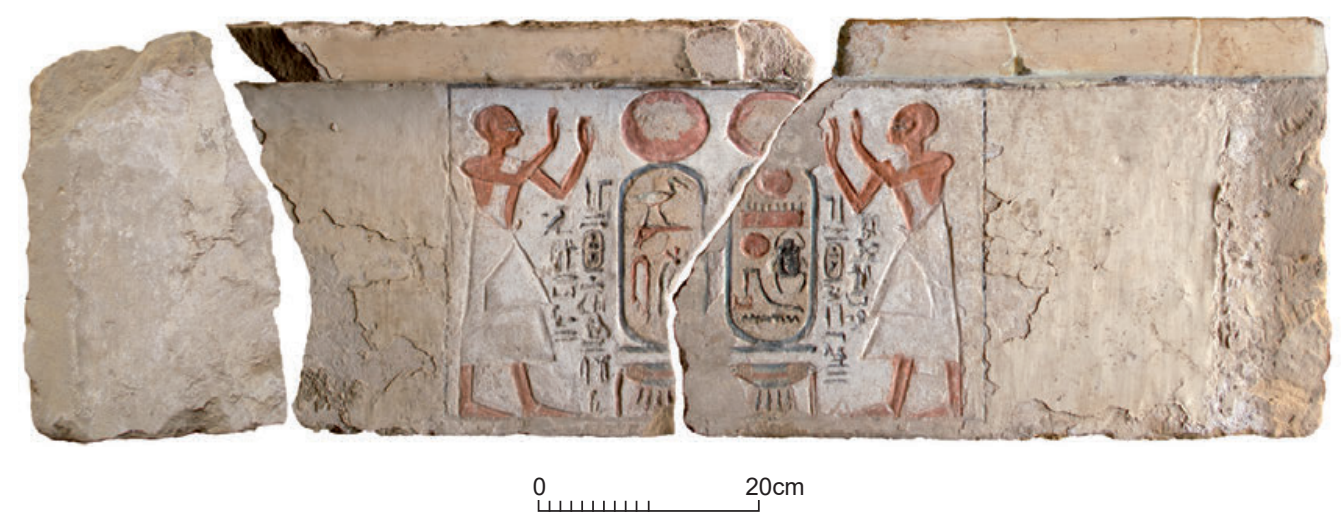

19. Sandstone lintel of Khonsu; inv. nos 15064C, 15064A and 15064B, from left to right (Phot. M. González Bustos (C) Thutmosis III Temple Project).

to the previous one, but with some differences. On the right side, two columns of text

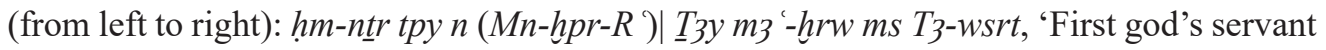
of (Menkheperre)|, Tjay, justified, born of Tausret'. On the left side, two columns of text (from right to left): hm-ntr tpy $n$ (Mn-hpr-R )| Hnsw m3'-hrrw ms $T_{3}-w[s] r t m_{3}{ }^{\prime}(t)-h r w$, 'First god's servant of (Menkheperre)|, Khonsu, justified, born of Tausret, justified'.

Khonsu was a priest who lived during the time of Ramesses II and was buried in TT 31, located behind the temple of Millions of Years of Thutmose III. ${ }^{52}$ The name 'Tjay' is his nickname. These lintels, currently displayed at the Luxor Museum, are clear evidence that the Temple of Thutmose III was still active during the reign of Ramesses II.

52 PM I.12, 47-49; Davies 1948: 11-26. Khonsu is listed also in: Al-Ayedi 2006: 356, no. 1197. 


\section{STATUES AND STELAE}

Numerous fragments of statues and stelae of different kinds of stone have been found, particularly of limestone and sandstone. Although the collection of statues has not yet been studied, it is already clear that some of them bear the names and ranks of their owners. Particularly important are the aforementioned lower parts of the diorite statue of Thutmose III (Fig. 20; 30.5 cm high, $12.5 \mathrm{~cm}$ wide and $27 \mathrm{~cm}$ deep) and the black granite seated statue of the royal scribe and child of the royal nursery, Ahmose (Fig. 21; 22.5cm high, $12.5 \mathrm{~cm}$ wide and $20 \mathrm{~cm}$ deep), both found in the house of Khonsu (Fig. 10). On the sides of the plinth of the Thutmose III statue there are depictions of figures of two foreigners, an Asiatic and a Nubian, with their bodies stretched out and their arms bent as a sign of submission. The hands were carved with their palms extended forward, towards the front part of the base. Their faces are now lost.

Two other interesting statue fragments preserve the names of two important men in the administration of Thutmose III. The first is part of a seated limestone statue containing the following inscription: [/// rp 't ḩ3ty]- 'imy-r niwt $\underline{t} 3 t y[W] s[r]-I m n$, ' $[/ / /$ the noble, the cou]nt, the overseer of the city [User]amun' (inv. no. 7723). This is one of the Viziers of the south who had an important position during the first years of Thutmose III. Useramun had two tombs, TT 61 and TT $131 . .^{53}$ The second is a fragment that retains part of an inscription that includes the name of the Overseer of the Seal, Senneferi (inv. no. 9068). ${ }^{54}$ This important official from the times of Thutmose III was buried in the TT 99. ${ }^{55}$

These officials obviously obtained the privilege of exhibiting a statue in this temple, as was also the case with the royal herald and architect Yamunedjeh, whose statue is in a very good condition, as can be seen nowadays in the Luxor Museum (inv. no. 3). It was found $200 \mathrm{~m}$ north-east of the pylon. ${ }^{56}$

To the important statues also belong two fragments found in the second courtyard, in the area of a foundation trench (Fig. 5) from which blocks were removed at an undetermined moment in the past. The first is a part of a head with a tripartite wig, stretch marks and delicate face, indicating that this belonged to a divinity (Fig. 23). This statue was made of granodiorite and demonstrates a high-quality of workmanship. It probably belongs to the time of Amenhotep III. Its dimensions are: $29.6 \mathrm{~cm}$ high, $24.3 \mathrm{~cm}$ wide and $26.9 \mathrm{~cm}$ deep. ${ }^{57}$ The second is a head and part of the torso of a statue of the goddess Sekhmet (Fig. 22), which was found to the north of the ramp. It was made of black granite and is missing the characteristic solar disc. Its dimensions are: $45 \mathrm{~cm}$ high, $40 \mathrm{~cm}$ wide and $40 \mathrm{~cm}$ deep. It is similar to statues found at the Temple of Amenhotep III at Kom el-Hettan. ${ }^{58}$

${ }^{53}$ For this tomb and this official biography, see: Dziobek 1998.

${ }^{54}$ Seco Álvarez et al. 2012-2013: 143; see also: Seco Álvarez, Martínez Babón 2019: 131.

${ }_{55}$ PM I.12 204-206; Strudwick 2016.

${ }^{56}$ For this statue, see: Hayes 1933: 6-16.

${ }^{57}$ Hourig Sourouzian, personal communication.

${ }^{58}$ See also Sekhmet statue from Ramesseum, as well as other statues from the times of Amenhotep III's found there: Lurson 2004; 2007; Gutmann, Richter 2014. 

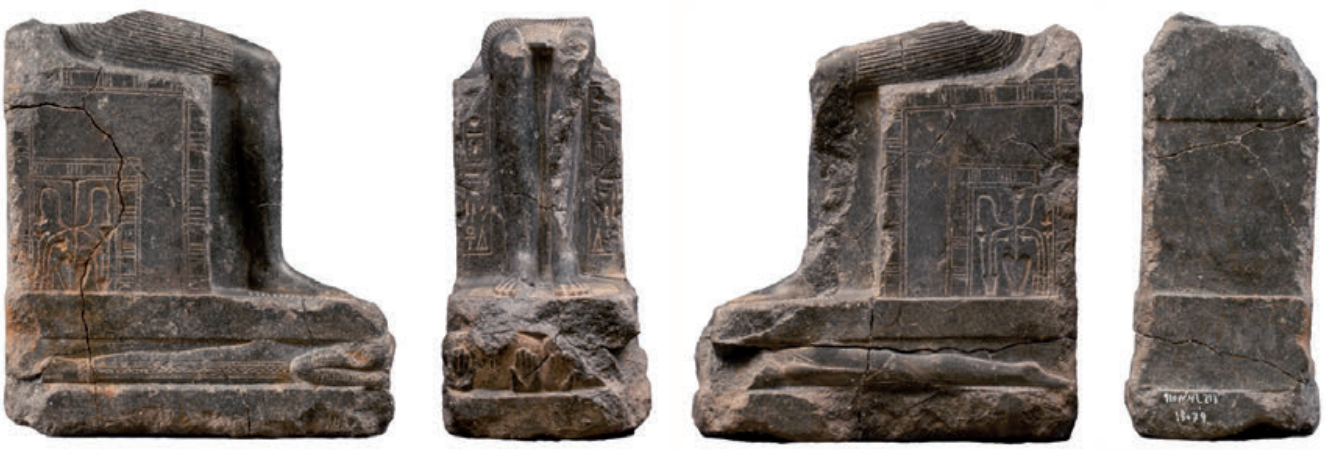

0 $10 \mathrm{~cm}$

Ш山ШШ

20. Statue of Thutmose III, inv. no. 15079 (Phot. M. González Bustos (C Thutmosis III Temple Project).
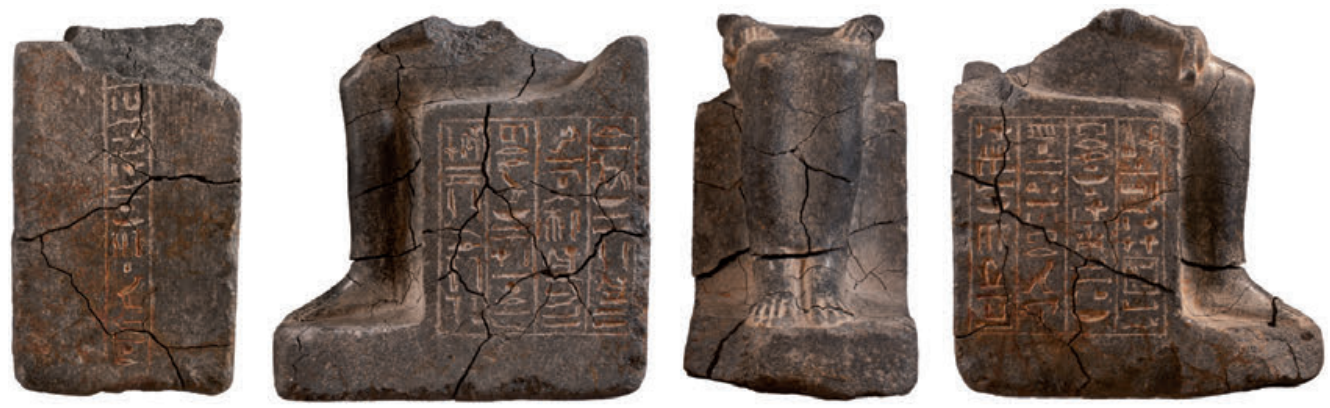

0 $10 \mathrm{~cm}$

21. Statue of the royal scribe Ahmose, inv. no. 15216 (Phot. M. González Bustos (C Thutmosis III Temple Project).
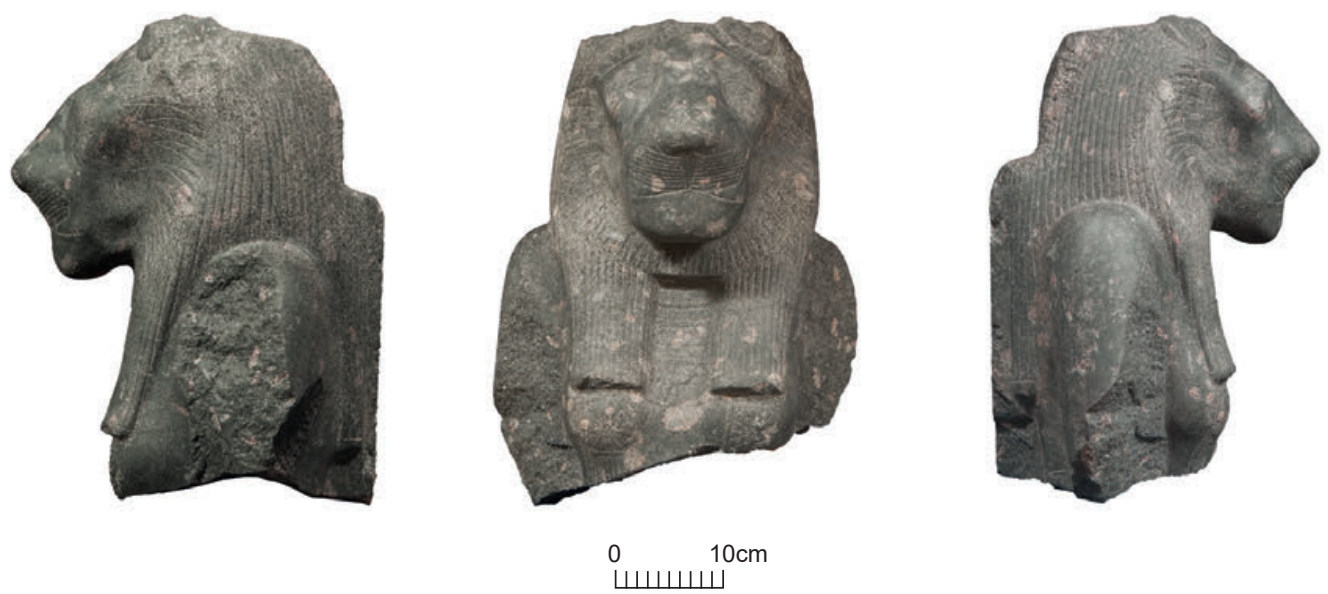

22. Head and part of the torso of statue representing goddess Sekhmet, inv. no. 9478 (Phot. I. García Martínez (C) Thutmosis III Temple Project). 


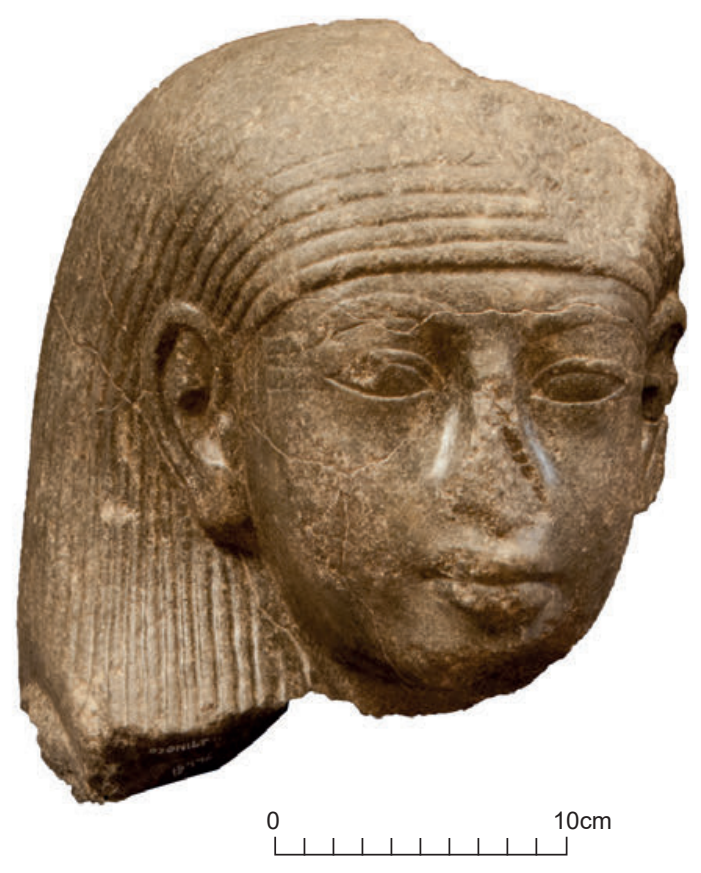

23. Head of a granodiorite statue, inv. no. 15442 (Phot. A. Amin (C) Thutmosis III Temple Project).

Almost three hundred fragments of stelae have been found in the Henket-ankh. Some of them are particularly well preserved. The majority are made of limestone, but there are also some carved of sandstone and red quartzite. ${ }^{59}$ Part of a large royal stela, which depicts Thutmose III and his mother Iset standing before Amun-Re, was found by Weigall. ${ }^{60}$ Apart from this object, the most important examples of votive stelae show the king as an intermediary between the donors and the gods. On some of them names and title of donors are preserved. The most commonly represented gods are Amun-Re and Hathor. The image and the name of the first appears damaged, because of the persecution of Amun during the reign of Akhenaten. This can be seen on some limestone stelae, such as inv. no. 15258 and inv. no. $15523 .{ }^{61}$ To the most interesting examples representing Hathor belongs inv. no. 9234. On this fragment there is the head of the divinity with its characteristic headdress of a sun disc flanked by horns, with the inscription reading: $\mathrm{Hwt}-\mathrm{Hr} n \mathrm{nt} H \mathrm{Hw}$-shm, 'Hathor, mistress of Hut-Sekhem', a town located in the seventh Nome of Upper Egypt. ${ }^{62}$

On many stelae animals that symbolised Amun are represented. The most common ones are rams, cobras, cows and geese. Especially significant, particularly for its beauty

\footnotetext{
59 Franco González 2019: 110-111.

${ }^{60}$ For the information about this stela, see: Weigall 1906: 128-136.

${ }^{61}$ Franco González 2018: 63-73, Fig. 5.

62 Franco González 2019: 132.
} 
24. Stela with geese representations, inv. no. 15491 (Phot. I. García Martínez (C) Thutmosis III Temple Project).

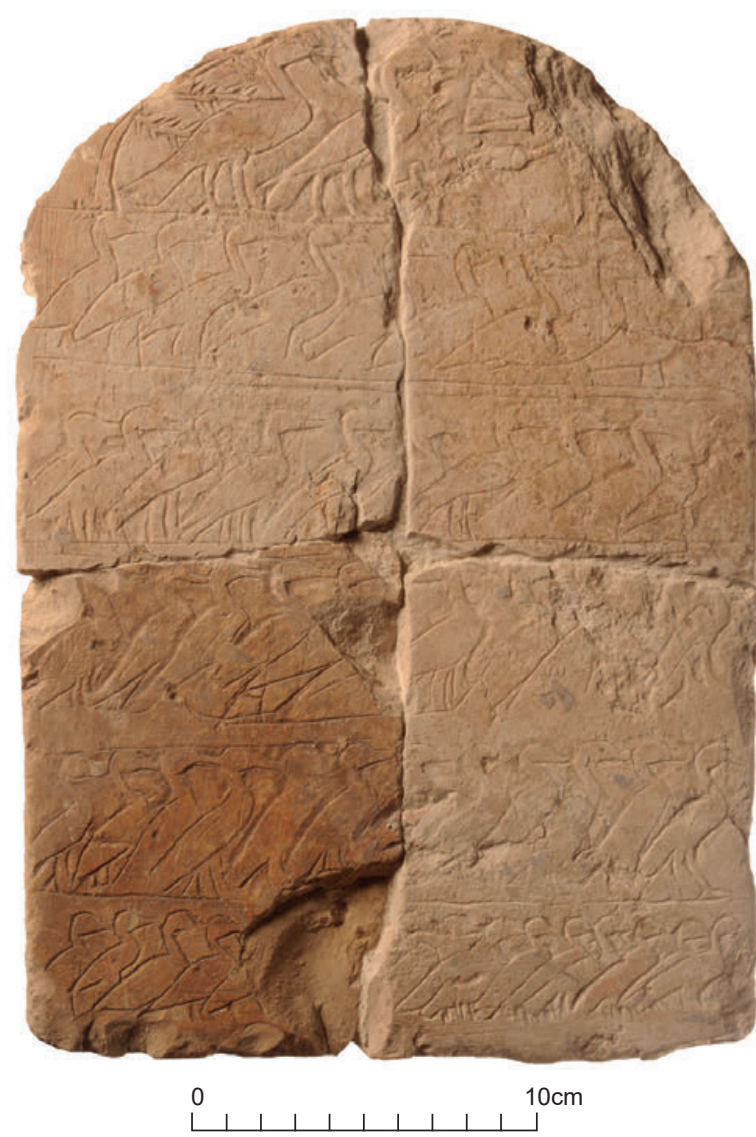

and meaning, are two almost complete limestone stelae showing rows of geese (inv. nos 15501/15491). ${ }^{63}$ The first one shows three registers, each one containing two geese, face to face, while the second ( $30.4 \mathrm{~cm}$ high, $21.1 \mathrm{~cm}$ wide and $4.3 \mathrm{~cm}$ deep) has five registers with rows of geese and a lunette in which two geese and plant motifs are represented (Fig. 24).

Most of these stelae are dated from the middle of the Eighteenth Dynasty to the beginning of the Nineteenth Dynasty, on the basis of epigraphic evidence, find context or both. ${ }^{64}$

Of particular importance are also four fragments forming a good portion of a limestone stela belonging to Re, a priest from the reign of Amenhotep II, who was buried in TT 72 (Fig. 25). ${ }^{65}$ The stela presents an oval lunette, which shows a winged solar disc, and below a seated figure of the god Amun-Re, an offering table, the figure of Thutmose III and two

63 Franco González 2019: 138-147 (zoomorphic representations).

${ }^{64}$ For more details on the stelae dating, see: Franco González 2019: 111.

65 Fragment inv. no. 15480, which contains the name of the official, was presented, along with other materials, during the V Iberian Congress of Egyptology, held in Cuenca, in 2015: Martínez Babón 2017: 608-609; see also: Seco Álvarez, Martínez Babón 2019: 132; Franco González 2019: 115; PM I.1², 142-143. 


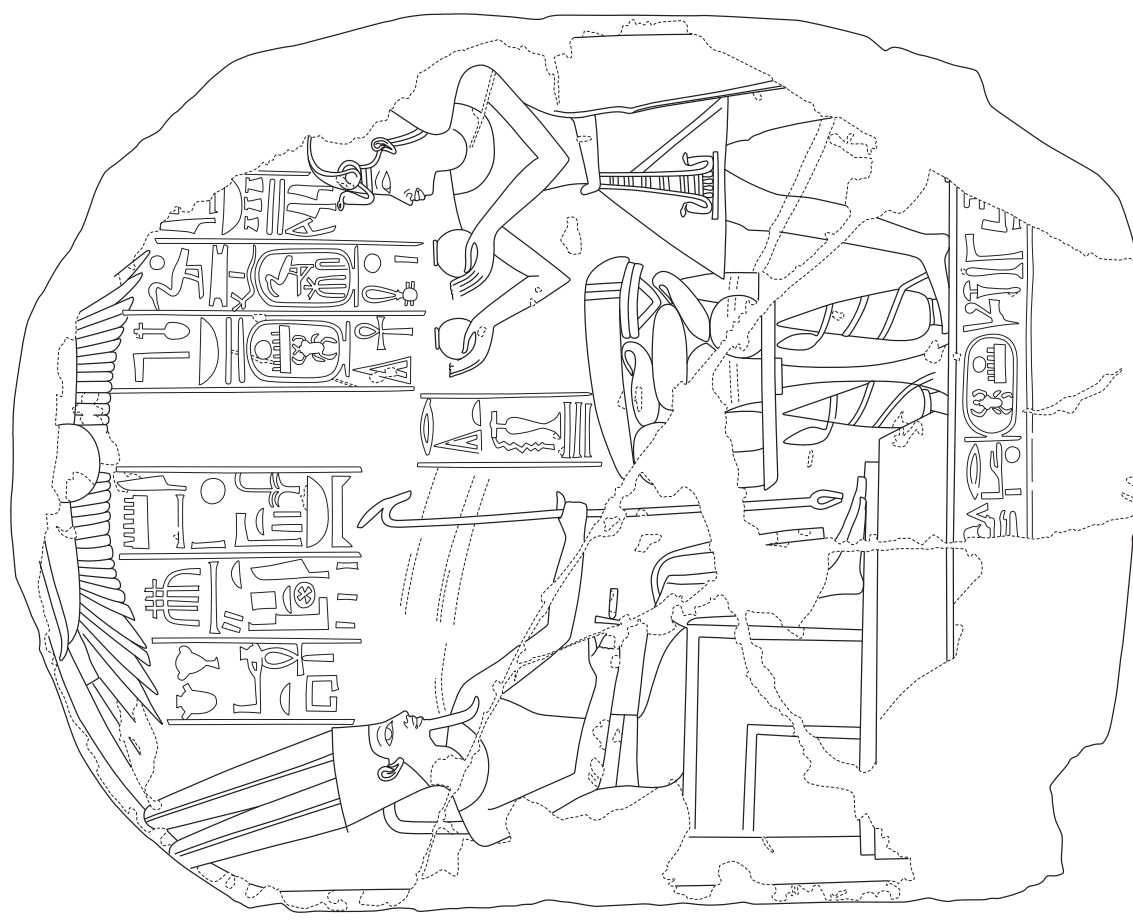


inscriptions related to the god and the king, as well as the following inscription at the base: [...] hm-ntr $\operatorname{tp}(y) n(M n-h p r-r) \mid R^{\prime}[\ldots]$, '[...] the first prophet of (Menkheperre)|, Re [...]'.

\section{FOUNDATION DEPOSIT}

The above-mentioned deposit, found near the entrance to the second courtyard (Fig. 5), includes six inscribed and one uninscribed stones reworked in the form of bricks of various sizes and made of quartzite, sandstone and red granite (Fig. 26). ${ }^{66}$ The four largest are covered by the following inscription: $n \underline{t} r n f r(M n-h p r-R) \mid m r[y]$ Imn (2) $h f t p \underline{d}-\check{s} s \underline{h r} h w t=f^{67}$ nt imntt, 'The good god (Menkheperre)|, beloved of Amun, at the time of the Stretching of the Cord over his temple of the West'. Two smaller ones bore the throne name of Thutmose III, Menkheperre. Some pottery vessels and cow bones were found within the deposit. ${ }^{68}$

\section{PAPYRI, OSTRACA AND GRAFFITI ${ }^{69}$}

Almost all the papyri currently inventoried originate from the same area of the site, namely the rubbish dumps to the north of the northern enclosure wall, which were formed mostly in the times when the temple was in use, but also during earlier archaeological works at the site. Some small fragments of administrative documents were found in the workshop area in the north-western corner of the temple precinct (inv. no. 21021).

The papyri fragments from the temple's dumps vary in terms of their content. Administrative documents are most numerous. They constitute part of the archive of the temple from the times of Eighteenth Dynasty. This collection includes dated entries with lists of commodities (different types of bread and cakes, honey, fruit, dates, milk, beer, wine, textiles), often in relatively small quantities. The documents probably represent daily offerings made in the temple: there are numerous fragments of headings in red ink. Several entries include various types of fowl and cattle, and incense is frequently mentioned.

There are also fragments mentioning different festivals, including a coronation festival, the well-known Nehebkau-festival (of the last day of the last month of the akhet-season), and an otherwise unattested 'festival of Amun during Khoiak'. It is known that festivals of victory commemorating Thutmose III's military campaigns in the Levant were also celebrated in the temple during his reign since the Annals of the king mention them. ${ }^{70}$

${ }^{66}$ With inscription: inv. nos 9385 (31.5 x $\left.16 \times 10.8 \mathrm{~cm}\right), 9386(33.8 \times 20.5 \times 8.4 \mathrm{~cm}), 9387$ (45.8 x $16 \times 9.8 \mathrm{~cm})$, and $9388(39 \times 17.5 \times 10.5 \mathrm{~cm})$; with cartouche: inv. nos $9389(21.5 \times 12.3 \times 7.4 \mathrm{~cm})$ and 9390 $(22.5 \times 10.8 \times 7.6 \mathrm{~cm})$.

67 The question as to whether the hieroglyph was used here or $\square$ to write $h w t$ is difficult to answer given the partially eroded condition of the stone. This applies to all four above mentioned objects.

${ }^{6}$ Seco Álvarez, Martínez Babón 2014: 157-167, Pls LXIII-LXV. Weigall and Ricke also found foundation deposits in various parts of the temple; see: Ricke 1938: 32-33; Weigall 1906: 125-126.

${ }^{69} \mathrm{~F}$. Hagen is responsible for studying this material. A publication is in preparation.

${ }^{70}$ Urk. IV, 741: 3-5. 


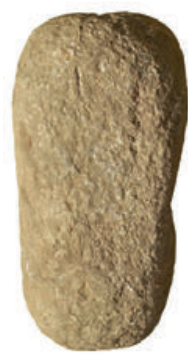

a

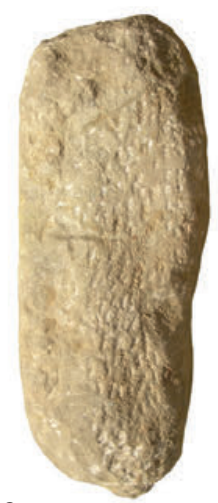

C
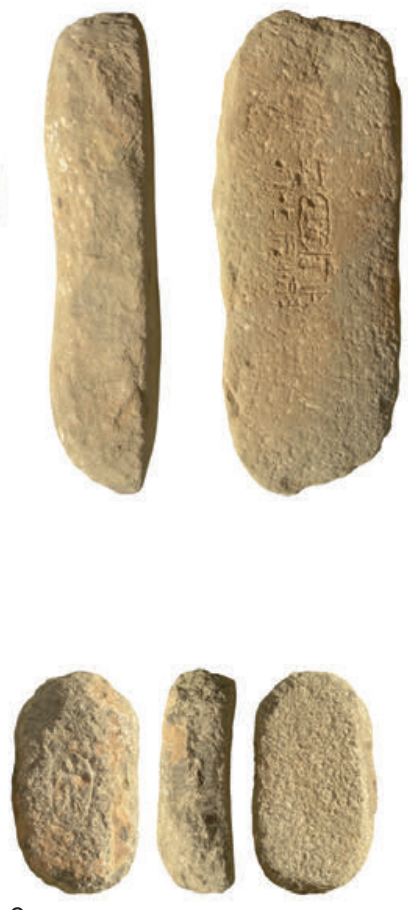

e
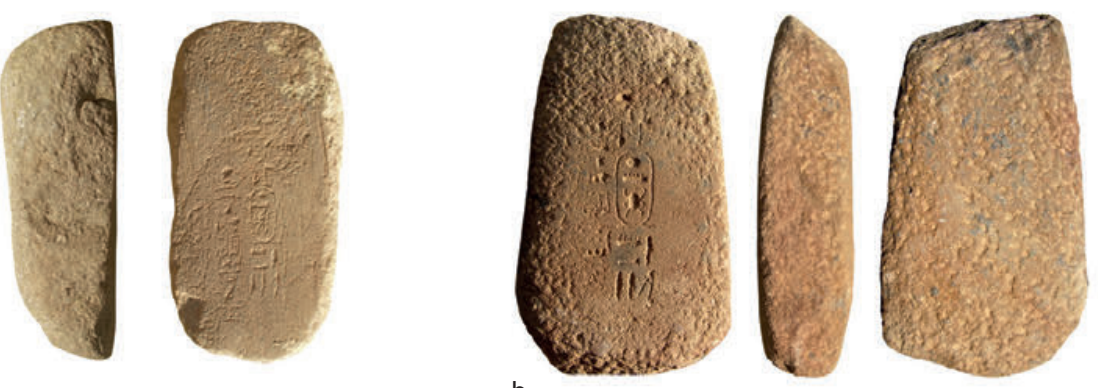

b
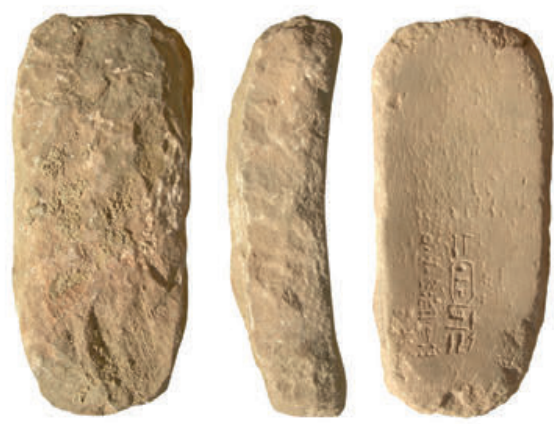

d
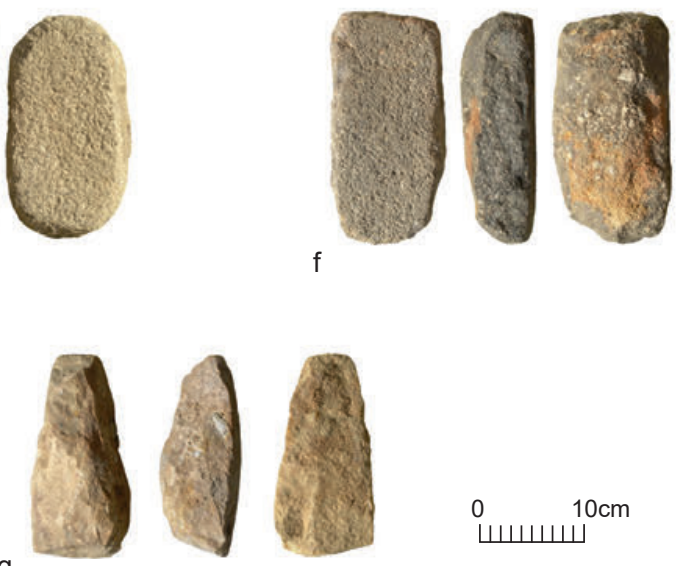

26. Foundation deposit from the area of entrance to the second courtyard: a. inv. no. 9385 ; b. inv. no. 9386; c. inv. no. 9387; d. inv. no. 9388; e. inv. no. 9389; f. inv. no. 9390; g. without inv. no. (Phot. A. Guío (C) Thutmosis III Temple Project). 
Mixed in with these administrative fragments, which essentially formed part of the daybook or journal of the temple, are some small fragments of other categories of manuscripts. The largest number of non-administrative fragments come from a papyrus roll with a religious text, written in cursive hieroglyphs in columns and a vignette with a standing 'stick figure' of a man. There are some fragments of an illustrated roll, different from the two described above, with drawings of snakes cut with knives in red ink, often with Hieratic captions (also in red). One mentions $m s w b d \check{s} t$, "children of the Weary One (or The Rebel?)', enemies of the sun-god, and another mentions Apophis.

Among the ostraca there are both limestone and ceramic examples, but the latter are a clear majority. These are administrative texts (lists of rations, of stone masons, and of wab-priests, letters or messages), as well as literary compositions, including several with dates in red ink at the end, a feature that has been associated with scribal training. Less ambiguous in that sense are copies of the text known as Kemit, which is well known as forming part of scribal education and appears in both good and bad handwriting.

An interesting example is the limestone ostracon (inv. no. 15670) with lists of the names of wab-priests (phyles) serving in the mortuary temple. In the middle is a heading reading 'second phyle'. There are lines dividing the separate groups of priests from each other. This ostracon contains the personal names of some of the priests serving in the temple during the Eighteenth Dynasty.

There are also some graffiti, most of which were made on sandstone and come from the temple proper. On these, the ink graffiti are invariably laid out so as to not overlap with the raised relief - in other words, they respect the original decoration of the temple. A few names are preserved in their entirety, for example: the wab-priest Kay (inv. no. 3257), Wennefer (inv. no. 3247), and the scribe Seth (inv. no. 13605). Another mentions the name of Thutmose III, presumably as part of the name of the temple (inv. no. 3246), and others record the gods, such as 'Amun-Re, king of the gods'.

\section{SEAL IMPRESSIONS AND STOPPERS}

Some seal impressions on clay have been found at the site. The majority are in a very poor state of preservation, but they have historical value since these seal impressions record the names of several pharaohs. The throne name of Thutmose III is the most common one (e.g. inv. nos 15489 or 21332). One impression contains the throne name of Amenhotep II (inv. no. 15631), and others the throne names of Thutmose III and Amenhotep III together (inv. nos 15229 and 15850). ${ }^{71}$

Most of the discussed objects bear inscriptions, although many of these are in a very poor state due the great fragility of the pieces. Allusions to wine offerings are plentiful, and occasionally, of honey. The onomastics are particularly interesting. Various names

${ }^{71}$ Franco González 2019: 274, 276, 278. 
of kings and queens cover a good part of the New Kingdom. They show that the figure of Thutmose III was revered throughout many later generations in his own temple of Millions of Years or that the temple was still functioning and received standard assignment from the central authority. ${ }^{72}$

The first pharaoh attested as delivering offerings is Thutmose IV. A fragment preserves his entire throne name, even though, sadly, the complete inscription was not preserved:

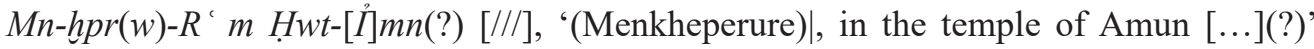
(inv. no. 15596). ${ }^{73}$ Other incomplete pieces could be attributed to this monarch, but with caution. Only the shape of the kheperu-signs in the lower part of the cartouche are preserved, and this circumstance generates doubt as to the throne name of Thutmose IV, particularly since it could also be attributed to Amenhotep II. One allows us to read [///] hprw Hwt-Imn '[///], 'kheperu [///], the temple of Amun' (inv. no. 9569) and the other [///] hprw 'nh $\underline{d} d$ wzs $n b$, '[///] kheperu [///], all life, duration and sovereignty' (inv. no. 15568). ${ }^{74}$

Amenhotep III and his wife Tiye also rendered homage to the image of Thutmose III through offerings. The throne name Nebmaatre can clearly be distinguished on one fragment, even though most of the remaining part of the inscription has been lost (inv. no. 15097). Other fragments allow for the identification of the name Nebmaatre Meryamun, although it appears incomplete (Fig. 27). ${ }^{75}$ As to the queen, an incomplete inscription can be read with some difficulty. However, the words ḥmt-nswt wr(t) Tyi(?), 'the great king's wife Tiye' are preserved (inv. no. 15273). ${ }^{76}$

On a piece of a clay vessel in a very poor state of preservation, the hieroglyphs $[/ / /] n(?)$ itn, 'of(?) Aten' appear in a cartouche. This was found in the workshop area in the northwestern corner of the temple (inv. no. 20857). ${ }^{77}$ It cannot be ruled out that this inscription should be related with Akhenaten. This pharaoh's activity in the temple is attested by the aforementioned defacement that was carried out against the figures of Amun in the inscriptions and reliefs, ${ }^{78}$ and stamped mudbricks in a wall located in the north-eastern sector of the excavation site. ${ }^{79}$

The next pharaoh whose throne name is found in this category of finds is Tutankhamun (inv. no. 20795). A stopper contains the inscription: irp $n$ pr (Nb-hprw-R )| grg Imn W3st $[/ / /]$, 'Wine of the House of (Nebkheperure)|, the Foundation of Amun of Thebes' ${ }^{80}$

72 Seco Álvarez, Martínez Babón, Moreno Cifuentes 2016: 101-115; Martínez Babón, Seco Álvarez, Moreno Cifuentes 2019: 169-188.

73 Seco Álvarez, Martínez Babón 2016: 111.

74 Seco Álvarez, Martínez Babón 2016: 108, 111.

75 This variant of the name can be found in: Gauthier 1912: 307, n. 3; 310, n. 1; 319. For a list of different variants of name with Nebmaatre, see: Von Beckerath 1984: 86. The discussed one is, however, not attested there.

76 This variant of the name can be found in: Gauthier 1912: 331-333, 355-356; Seco Álvarez, Martínez Babón 2016: 109.

77 Seco Álvarez, Martínez Babón 2016: 115.

78 Seco Álvarez, Martínez Babón 2015c: 525-536.

79 Seco Álvarez, Martínez Babón 2015a: 383.

${ }^{80}$ Seco Álvarez, Martínez Babón 2016: 115. 


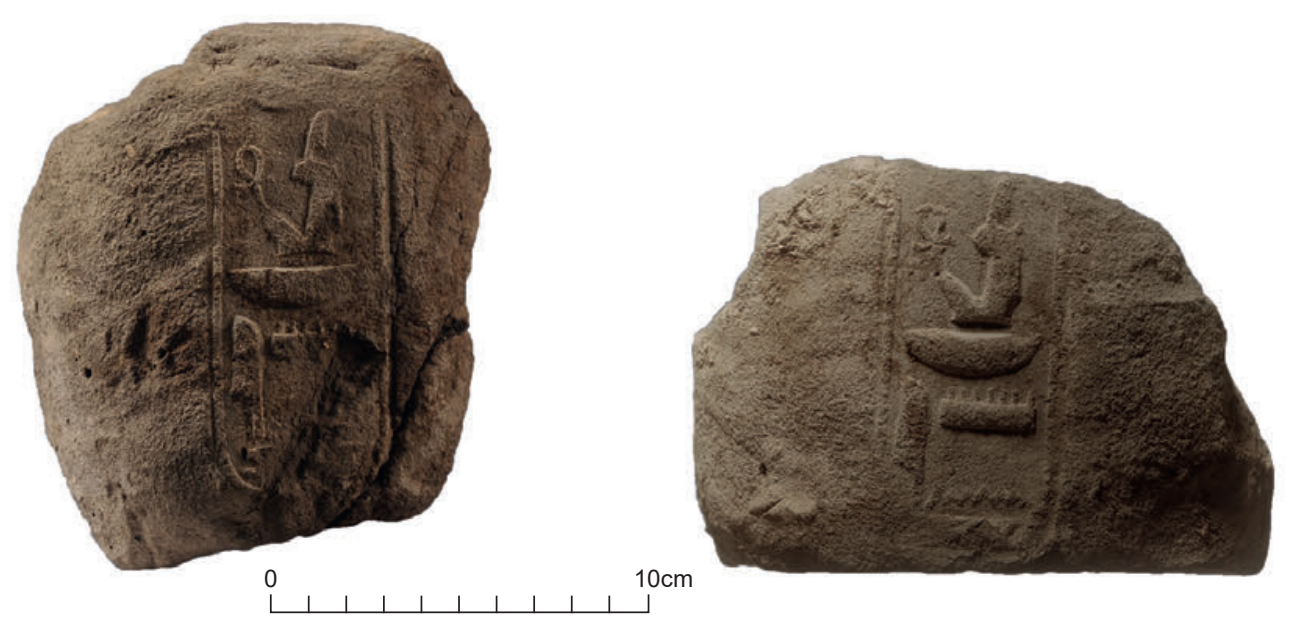

27. Impressions with the name Nebmaatre Meryamun, inv. nos 15048 and 15664, from left to right (Phot. J.C. Lara Bellón (C) Thutmosis III Temple Project).

There are also some clues, that despite the significant political deterioration, this type of offerings was delivered also in the time of Horemheb, the last pharaoh of the Eighteenth Dynasty. His throne name, though incomplete, can be identified on two fragments (inv. nos 15610 and 20780). ${ }^{81}$

Additionally, the first kings of the Nineteenth Dynasty left tokens of respect for the figure of Thutmose III. Various stoppers were found that bear labels with the words Mn-phty-R 'irp, 'Menpehtyre wine' (inv. nos 20784 and 20790). ${ }^{82}$ Despite his brief reign, Ramesses I wanted to leave an offering to the memory of the conqueror pharaoh. It appears that the stoppers with the throne name of this pharaoh are so far the only ones that have traces of an inscription on their bases. Unfortunately, they are very deteriorated, although, for example on inv. no. 20791 we can distinguish the $n f r$-sign and a cobra over the $n b$-sign.

Although incomplete, one inscription bears the throne name of Seti I: Hwt-Imn $\mathrm{m} \mathrm{pr}$ ([Mn- $\left.] m_{3}{ }^{\prime} t-R\right) \mid \operatorname{irp} n f r(?)$, 'good wine of the temple of Amun in the House of ([Men] maatre)|(?)' (inv. no. 20781) ${ }^{83}$ We cannot forget that this monarch, like Thutmose III, had a significant military role and conducted campaigns against the enemies of Egypt in the Near East.

The last important figure, from a chronological point of view, whose name is attested on stoppers is that of queen Nefertari. There are two fragments preserved: one, which is in

${ }^{81}$ It is interesting to find the name written with two scarabs, since the name of this pharaoh was generally written with a single scarab.

${ }^{82}$ Seco Álvarez, Martínez Babón 2016: 114.

${ }^{83}$ Seco Álvarez, Martínez Babón 2016: 113. 

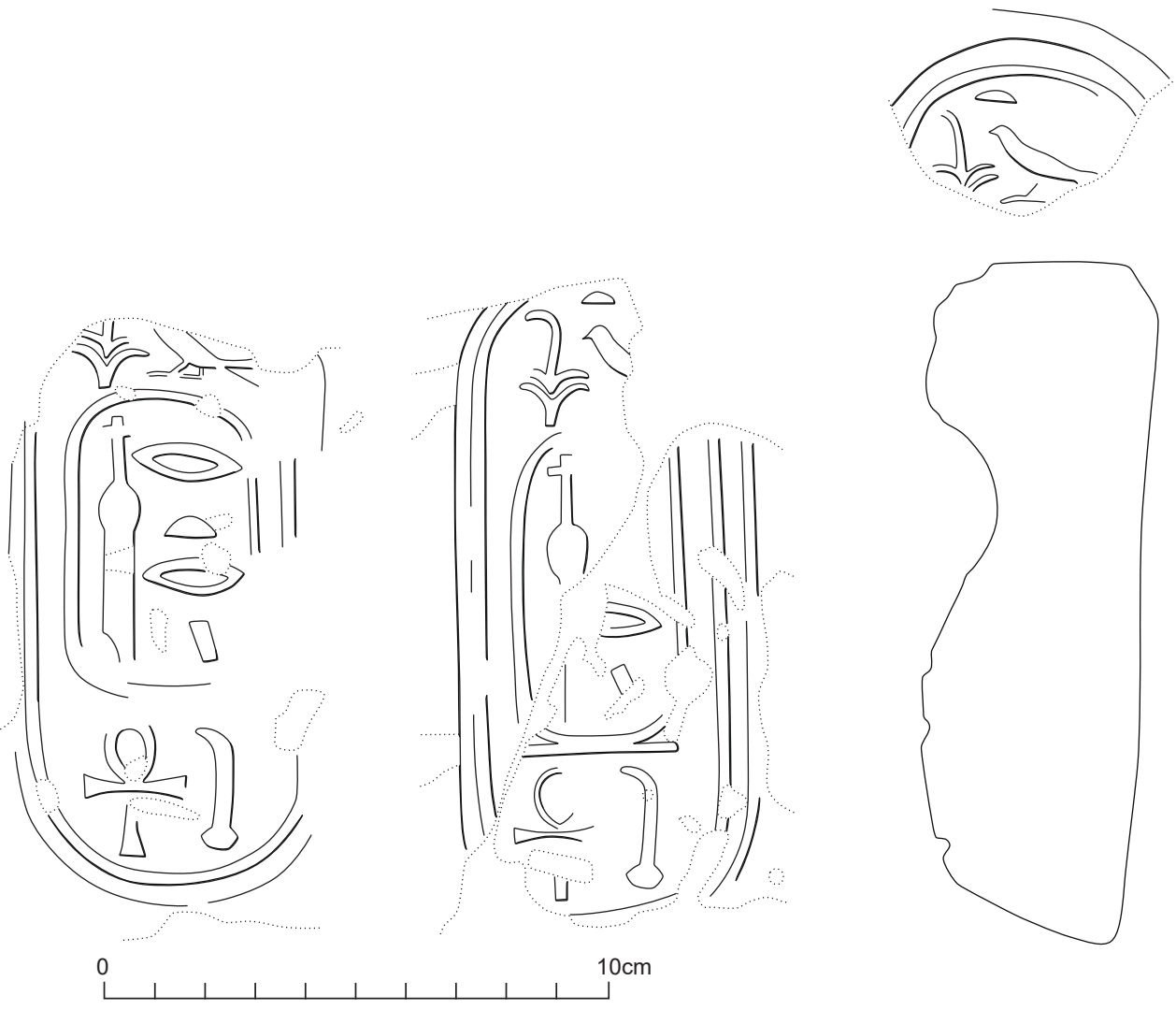

28. Stoppers with name of Nefertari, king's wife, inv. nos 15478 and 15477 (Drawing: P. Calassou (C) Thutmosis III Temple Project).

a bad state of preservation, and contains the words: [hmt]-nswt wrt (Nfrt-iry)| 'nh.ti' 'the great king's [wife] Nefertari, who lives' (inv. no. 15478) ${ }^{84}$ while on the other (inv. no. 15477) we can distinguish the end of the name of the queen with the corresponding formula: [hmt-nswt wrt Nfrt-]iry(?) 'nh.ti, '[the great king's wife Nefert]ari(?) who lives' (Fig. 28). ${ }^{85}$

\section{MUDBRICKS}

The excavation and restoration works conducted by the mission have allowed for the recovery of numerous stamped mudbricks that significantly expand the list published by Ricke. ${ }^{86}$ Apart from a series of types related to the throne name of Thutmose III or

${ }^{84}$ Seco Álvarez, Martínez Babón 2016: 110.

85 See: Seco Álvarez, Martínez Babón 2016: 110; Seco Álvarez, Martínez Babón, Moreno Cifuentes 2016 : 106.

${ }^{86}$ Ricke 1938: 33-36. 


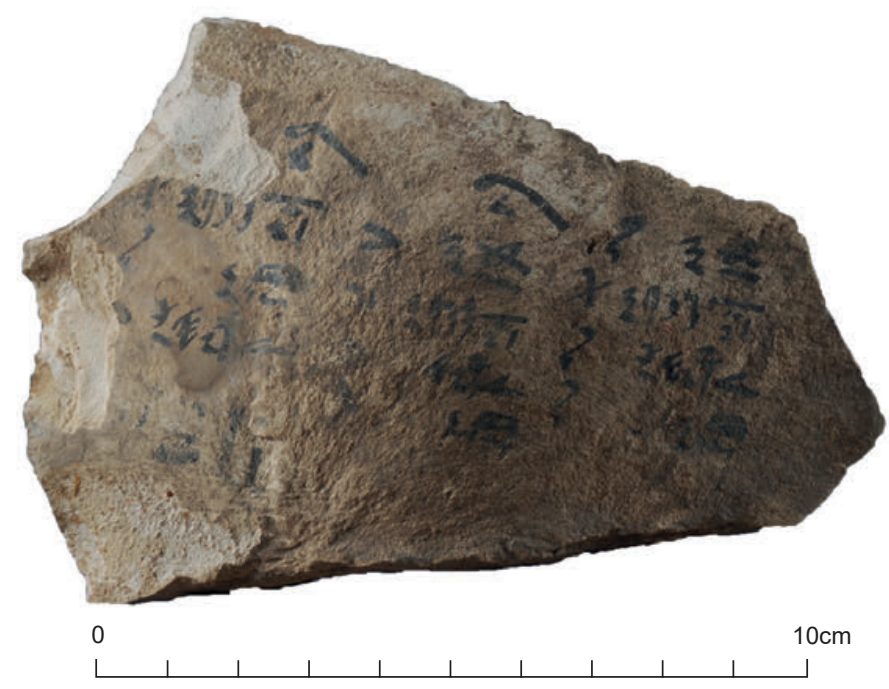

29. Limestone ostracon with hieratic text giving recipe for mudbricks, inv. no. 15131 (Phot. I. García Martínez (C) Thutmosis III Temple Project).

the name of the temple, the names of other pharaohs could be identified among them. Thus, it is worth mentioning types that include the throne names of Thutmose I and Hatshepsut (together), Thutmose I, Hatshepsut, Amenhotep IV and Ramesses II. This material is being studied in order to better understand the construction phases of the previously discussed architectural structures.

Moreover, on numerous mudbricks more than twenty different marks were recorded, which most likely correspond to the teams of workers that built the temple. In this context, an ostracon found on the site (inv. no. 15131) with three columns of hieratic text, largely complete except for a flake missing on the left edge (Fig. 29), should be highlighted. It presents three recipes for mudbricks, all with varying amounts of clay, straw, sand and something called $n m s$-soil. Water is not mentioned but would obviously have been used to bind the mixture together. ${ }^{87}$

\section{CONCLUSIONS}

After twelve field seasons of research at the Temple of Millions of Years of Thutmose III, among the most important results of research one should mention the completion of excavations and the reconstruction of the mudbrick enclosure wall. Moreover, part of the pylon and the central ramp have been restored. Investigation allowed the mission to expose some so far unknown complexes: administrative building outside the southern enclosure wall,

${ }^{87}$ See F. Hagen forthcoming publication entitled 'Ostraca from the temple of Millions of Years of Tuthmose III'. 
foundations of workshops to the North of the upper courtyard, and remains of the house of the Ramesside priest called Khonsu to the northeast of the second courtyard as well as foundation deposit at the entrance to this courtyard.

The excavation of the large dump located outside the northern enclosure wall of the temple has provided an enormous quantity of vessels, stelae fragments, ostraca and stoppers, which has provided remarkable information about the temple daily life.

Important data was also provided by an analysis of the moveable finds. Stamps and marks found on mudbricks allowed us to better understand the construction phases of the temple. Fragments of reliefs and architectural decoration, including 9257 sandstone and 2705 limestone fragments, provided religious and historical data on the decorative program of complex. 298 stelae and their fragments preserve epigraphic and iconographic information on religious and historical figures who had some relationship with the temple. Most of the hundreds of statue fragments still awaits study. Ostraca, parts of papyrus and various objects of daily life help to understand rituals and other activities that were carried out in the temenos. Abundant pottery from different eras and contexts allowed us to establish the chronological and economical background of the temple, while stoppers and earthenware containers that preserve inscriptions indicate that many pharaohs and important figures of the Royal House were interested in leaving offerings of wine and honey for the memory of one of the most important pharaohs in the history of Egypt.

There are still sectors of the temple to be excavated, which will likely contribute to a better understanding of a temple that was built in the time of Hatshepsut and Thutmose III and which was active until the reign of Ramesses II as far as the materials investigated indicate.

\section{Acknowledgements}

The project was initiated in 2008, as an active collaboration between the Ministry of Antiquities, the Academy of Fine Arts Santa Isabel de Hungría of Sevilla and the University of Seville. After months of formal negotiations with the Egyptian authorities, in which the participation of the Spanish Embassy in Cairo was helpful, we obtained permits to excavate and restore the Henket-ankh. Currently the project is sponsored by the Botín Foundation, Santander Universidades, the Cajasol Foundation and the Gaselec Foundation. We would like to express our gratitude to the Ministry of Antiquities for allowing us to work at the site and to the above mentioned institutions for funding of the project.

\section{References}

Al-Ayedi, A.R. 2006: Index of Egyptian Administrative, Religious and Military Titles of the New Kingdom, Ismailia

Arnold, Di. 1975: Deir el-Bahari, [in:] LÄ I, 1017-1025

Arnold, Di. 1979: The Temple of Mentuhotep at Deir el-Bahari, PMMA 21, New York

Bader, B., Seco Álvarez, M. 2016: Results of five years of pottery analysis in the Temple of Millions of Years of Thutmosis III in Western Thebes (2011-2015), ÄgLev XXVI, 157-262 
Beckerath, J. von 1984: Handbuch der ägyptischen Königsnamen, MÄS 20, München Chapon, L. 2016: Une possible représentation de l'arbre $j \check{s} d$ dans le temple de Millions d'Années de Thoutmosis III à Thèbes-Ouest, BIFAO 116, 47-56

Chapon, L. 2018a: Some Reliefs Representing the King in the Heb Sed Robe Discovered in the Henket-Ankh, EtudTrav XXXI, 123-143

Chapon, L. 2018b: Le Temple de Millions d'Années de Thoutmosis III. Étude du programme iconographique sur grès, unpublished $\mathrm{PhD}$ thesis, Granada University, Granada

Chapon, L. 2020: The Decoration of the Columns and Pillars from the Henket-ankh of Thutmose III (Western Thebes), EtudTrav XXXIII, 33-72

Daressy, G. 1926: Le voyage d'inspection de M. Grébaut en 1889, ASAE XXVI, 1-22

Davies, N. de G. 1948: Seven Private Tombs at Kurnah, Mond Excavations at Thebes II, London

Dziobek, E. 1998: Denkmäler des Vezirs User-Amun, SAGA 18, Heidelberg

Franco González, M. 2018: The damnatio against Amun-Ra in five private stelae discovered in the Temple of Millions of Years of Thutmose III in the West Bank, AulOr 36/1, 63-73

Franco González, M. 2019: Material evidence from the Temple of Millions of Years of Thutmose III: Study and interpretation of Votive and Daily Use Objects, unpublished PhD thesis, Granada University, Granada

Gamal-Eldine, M. 1981: Dress in Ancient Egypt, Cairo

Gamarra Campuzano, A. 2015: Conservation of the mudbrick structures in the Temple of Millions of Years of Thutmose III, [in:] Seco Álvarez, M., Jódar Miñarro, A. (Eds), The Temples of Millions of Years in Thebes, Granada, 273-291

Gauthier, H. 1912: Le livre des rois d'Égypte II. De la XIII' ${ }^{\mathrm{e}}$ dynastie à la fin de la XVIII dynastie, MIFAO XVIII, Le Caire

Griffin, K. 2017: Toward a better understanding of the Ritual of the Hours of the Night (Stundenritual), [in:] Pischikova, E. (Ed.), Tombs of the South Asasif necropolis: new discoveries and research 2012-14, Cairo-New York, 97-134

Gutmann, T., Richter, N. 2014: Eine falkenköpfige Seele aus dem Grabungsmagazin des Ramesseum, Memnonia XXV, 53-61

Hayes, W.C. 1933: A Statue of the Herald Yamu-nedjeh in the Egyptian Museum, Cairo, and Some Biographical Notes on its Owner, ASAE XXXIII, 6-16

Hölscher, U. 1934: The Excavation of Medinet Habu I: General Plans and Views, OIP 21, Chicago

Iwaszczuk, J. 2016a: Sacred landscape of Thebes during the reign of Hatshepsut. Royal construction projects. Volume 1. Topography of the West Bank, Travaux de l'Institut des Cultures Méditerranéennes et Orientales de l'Académie Polonaise des Sciences 2, Varsovie

Iwaszczuk, J. 2016b: Sacred landscape of Thebes during the reign of Hatshepsut. Royal construction projects. Volume 2. Topographical bibliography of the West Bank, Travaux de l'Institut des Cultures Méditerranéennes et Orientales de l'Académie Polonaise des Sciences 3, Varsovie 
Jacquet, J. 1994: Karnak-Nord VII. Le Trésor de Thoutmosis I ${ }^{\text {er }}$. Installations antérieures ou postérieures au monument, FIFAO XXXVI/1, Le Caire

Karakhanyan, A., Avagyan, A. 2010: The temple of Amenhotep III at Kom el-Hettan: evidence of a strong earthquake between 1200 and 900 B.C., [in:] Lebanc, C., Zaki, G. (Eds), Les temples de millions d'années et le pouvoir royal à Thèbes au Nouvel Empire : sciences et nouvelles technologies appliquées à l'archéologie, Colloque international, Bibliothèque publique Moubarak, Louqsor, 3-5 janvier 2010, Memnonia, Cahier supplémentaire 2, Le Caire, 265-270

Karakhanyan, A., Avagyan, A., Gevorgyan, M., Sourouzian, H., López Roa, C. 2014: Evidence of a strong earthquake in the period between 1200 and $900 \mathrm{BC}$ identified in the temple of Amenhotep III and in other temples of the ancient Thebes, [in:] Capriotti Vittozzi, G. (Ed.), Egyptian curses 1: Proceedings of the Egyptological Day held at the National Research Council of Italy (CNR), Rome $3^{\text {rd }}$ December 2012 in the International Conference "Reading catastrophes: methodological approaches and historical interpretation. Earthquakes, floods, famines, epidemics between Egypt and Palestine. $3^{\text {rd }}-1^{\text {st }}$ millennium BC. Rome, $3^{\text {rd }}-4^{\text {th }}$ December 2012, CNR- Sapienza University of Rome", Archaeological Heritage \& Multidisciplinary Egyptological Studies 1, Rome, 43-62

Karakhanyan, A., Avagyan, A., Stadelmann, R. 2014: Geological and archaeoseismological investigations at the Colossi of Memnon from 2009 to 2012, ASAE 87, 61-90

Karkowski, J. 2003: The Temple of Hatshepsut. The Solar Complex, Deir el-Bahari VI, Varsovie

Laboury, D. 1998: La statuaire de Thoutmosis III : essai d'interprétation d'un portrait royal dans son contexte historique, AegLeod 5, Liège

Legrain, G. 1906: Notes d'inspection XXXVII sur le temple Manakhpirri-Henq-ankh, ASAE VII, 183-187

Lipińska, J. 1977: The Temple of Tuthmosis III. Architecture, Deir el-Bahari II, Varsovie Lurson, B. 2004: Les Sekhmet retrouvées au Ramesseum, Memnonia XV, 103-122

Lurson, B. 2007: Note complémentaire sur la statuaire d'Amenhotep III retrouvée au Ramesseum, Memnonia XVII, 91-93

Lurson, B. 2017: Histoire d'une métamorphose : le temple de Touy de Ramsès II à Ptolémée IX, [in:] Lurson, B. (Ed.), De la mère du roi à l'épouse du dieu : première synthèse des résultats des fouilles du temple de Touy et de la tombe de Karomama / Von der Königsmutter zur Gottesgemahlin: erste Synthese der Ausgrabungsergebnisse des Tempels vos Tuja und des Grabes von Karomama, Connaissance de l'Egypte Ancienne 18, Bruxelles, 159-187

Martínez Babón, J. 2012: Fragmentos de relieves de carácter militar en el templo funerario de Tutmosis III, [in:] De Araújo, L.M., Das Candeias Sales, J. (Eds), IV Congreso Ibérico de Egiptología, Novos trabalhos de Egiptologia Ibériaca II, Lisboa, 669-677

Martínez Babón, J. 2015: Epigraphic and iconographic aspects of the Temple of Millions of Years of Thutmose III, [in:] Seco Álvarez, M., Jódar Miñarro, A. (Eds), The temples of millions of years in Thebes, Granada, 245-272 
Martínez Babón, J. 2017: Personajes históricos cuyos nombres se han encontrado en materiales del templo de Millones de Años de Tutmosis III, [in:] Burgos Bernal, L., Pérez Largacha, A., Vivas Sainz, I. (Eds), Actas V Congreso Ibérico de Egiptología, Cuenca 9-12 de marzo 2015, Cuenca, 603-611

Martínez Babón, J., Seco Álvarez, M., Moreno Cifuentes, M.A. 2019: Estudio preliminar sobre tapones hallados en el Templo de Millones de Años de Tutmosis III en Luxor (Egipto), Boletín del Museo Arqueológico Nacional 38, 169-188

Maruéjol, F. 2007: Thoutmosis III et la corégence avec Hatchepsout, Paris

Navarro, A., Ramirez-Casas, J., Gamarra, A., Seco Álvarez, M. 2014: La cal en el antiguo Egipto, [in:] Alejandre, F.J. et al. (Eds), La Cal, Investigación, Patrimonio y Restauración, Seville, 27-38

Naville, E. 1895: The Temple of Deir el-Bahari. Part I. The North-Western End of the Upper Platform, MEEF 13, London

Naville, E. 1901: The Temple of Deir el-Bahari. Part IV. The Shrine of Hathor and the Southern Hall of Offerings, MEEF 19, London

Naville, E. 1906: The Temple of Deir el-Bahari. Part V. The Upper Court and Sanctuary, $M E E F$ 27, London

Ricke, H. 1939: Der Totentempel Thutmoses' III, $B \ddot{A B} A$ 3/1, Kairo

Robichon, G., Varille, A. 1936: Le temple du Scribe royal Amenhotep fils de Hapou I, FIFAO XI, Le Caire

Seco Álvarez, M., Martínez Babón, J. 2014: A Foundation deposit in the temple of Millions of Years of Thutmose III in Luxor, Memnonia XXV, 157-167

Seco Álvarez, M., Martínez Babón, J. 2015a: A Ramesside Building in the Temple of Millions of Years of Thutmose III in Luxor, SAK 44, 383-391

Seco Álvarez, M., Martínez Babón, J. 2015b: Stela of the Priest Ra found in the Temple of Millions of Years of Thutmosis III, Memnonia XXVI, 129-135

Seco Álvarez, M., Martínez Babón, J. 2015c: La damnatio contra Amón en la capilla de caliza del templo de Millones de Años de Tutmosis III en Luxor, [in:] Castellano, N. et al. (Eds), Ex Aegypto lux et sapientia, Homenatge al professor Josep Padró Parcerisa, NSAeg IX, Barcelona, 525-536

Seco Álvarez, M., Martínez Babón, J. 2019: Historical Characters Linked to the Temple of Millions of Years of Thoutmosis III, Memnonia XXIX, 131-139

Seco Álvarez, M., Martínez Babón, J., Moreno Cifuentes, M.A. 2016: Preliminary Study about the Stoppers found in the Temple of Millions of Years of Thutmosis III, Memnonia XXVII, 101-115

Seco Álvarez, M., Radwan, A., Martínez Babón, J., Noureddine, I., Wilson, E., Guio, A., Kamimura, E., Gamarra Campuzano, A., Mora Ruedas, E., Moreno Cifuentes, M.A., Bader, B., Pazos, F., Karim, F.Y. abd el, Nouby, E. el, Khairi Mohamed, F. 2012-2013: Second and Third Excavation Season of the Egyptian-Spanish Project at the Mortuary Temple of Thutmosis III at the West Bank of Luxor (2009 and 2010), ASAE 86, 329-395

Sourouzian, H. et al. 2011: Fifth report on excavation and conservation work at Kôm el-Hettan from $9^{\text {th }}$ to $12^{\text {th }}$ seasons $(2007-2010)$ by the Colossi of Memnon and 
Amenhotep III Temple Conservation Project. Part I: The Colossi of Memnon and archaeoseismology, ASAE 85, 273-327

Sourouzian, H. 2014: Colossal statues of Amenhotep III collapsed due to an earthquake in antiquity at Thebes, [in:] Capriotti Vittozzi, G. (Ed.), Egyptian curses 1: Proceedings of the Egyptological Day held at the National Research Council of Italy (CNR), Rome $3^{\text {rd }}$ December 2012 in the International Conference "Reading catastrophes: methodological approaches and historical interpretation. Earthquakes, floods, famines, epidemics between Egypt and Palestine. $3^{\text {rd }}-1^{\text {st }}$ millennium BC. Rome, $3^{\text {rd }}-4^{\text {th }}$ December 2012, CNR - Sapienza University of Rome", Archaeological Heritage \& Multidisciplinary Egyptological Studies 1, Rome, 23-41

Stadelmann, R. 2014: The colossi of Memnon and the earthquakes at Thebes, [in:] Capriotti Vittozzi, G. (Ed.), Egyptian curses 1: Proceedings of the Egyptological Day held at the National Research Council of Italy (CNR), Rome $3^{\text {rd }}$ December 2012 in the International Conference "Reading catastrophes: methodological approaches and historical interpretation. Earthquakes, floods, famines, epidemics between Egypt and Palestine. $3^{\text {rd }}-1^{\text {st }}$ millennium BC. Rome, $3^{\text {rd }}-4^{\text {th }}$ December 2012, CNR - Sapienza University of Rome", Archaeological Heritage \& Multidisciplinary Egyptological Studies 1, Rome, 5-22

Strudwick, N. 2016: The Tomb of the Pharaoh's Chancellor Senneferi at Thebes TT99, Oxford

Thutmosis III Temple Project: www.thutmosisiiitempleproject.org (accessed January, 2020)

Vogelsang-Eastwood, G. 1992: Patterns for Ancient Egyptian Clothing, Leiden

Weigall, A.E.P. 1906: A report on the excavation of the Funeral Temple of Thoutmosis III at Gurneh, ASAE VII, 121-141

Weigall, A.E.P. 1907: Note additionnelle, ASAE VIII, 286

Winlock, H.E. 1932: The Museum's Excavations at Thebes, BMMA 27/3, 1-37

Wysocki, Z. 1986: The Temple of Queen Hatshepsut at Deir el Bahari. Its Original Form, MDAIK 42, 213-228

Wysocki, Z. 1992: The Temple of Queen Hatshepsut at Deir el Bahari: The Raising of the Structure in View of Architectural Studies, MDAIK 48, 233-254

Zoffili, E. 1992: Kleidung und Schmuck im alten Ägypten, Frankfurt a/Main 


\section{ÉTUDES et TRAVAUX XXXIII / 2020}
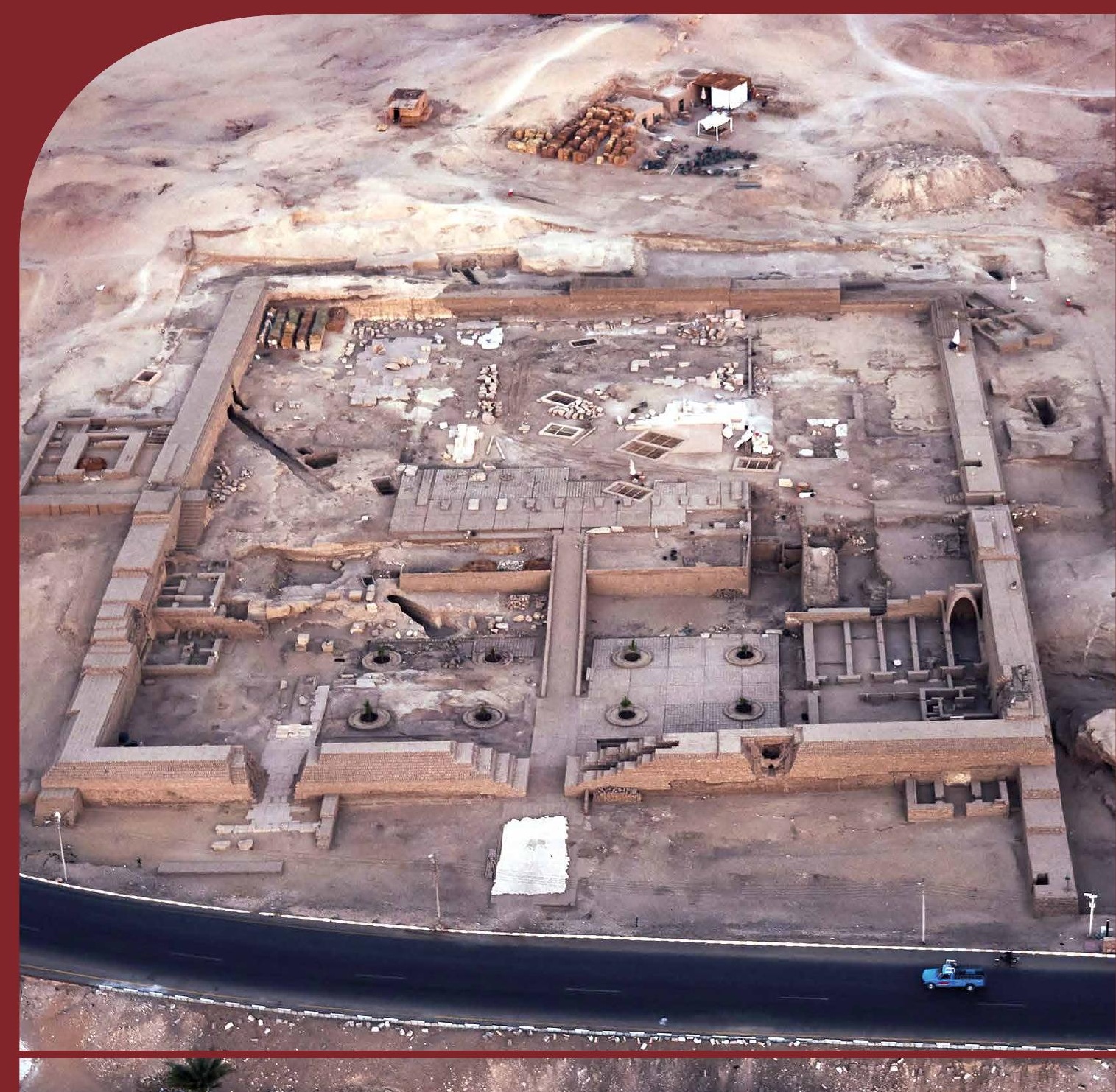

BOPIKSiO Institut des Cultures Mediterranéennes et Orientales IST PAN de l'Académie Polonáise des Sciences 


\title{
COMITÉ DE RÉDACTION SCIENTIFIQUE
}

Maciej Makowski - rédacteur en chef Jadwiga Iwaszczuk - rédacteur

Agnieszka Ryś - secrétaire de la rédaction

Ewa Laskowska-Kusztal - rédacteur thématique du volume

CONSEIL SCIENTIFIQUE DU JOURNAL

Michał Kobusiewicz (IAE PAN, Warszawa)

Ewa Laskowska-Kusztal (IMOC PAS, Warszawa)

Demetrios Michaelides (University of Cyprus, Nicosia)

Jean-Charles Moretti (IRAA-MOM, Université de Lyon 2/CNRS)

Dietrich Raue (Ägyptisches Museum der Universität Leipzig)

Paul Reynolds (ICREA, España)

Derek Welsby (British Museum, London)

COMITÉ SCIENTIFIQUE DE LECTURE

la liste des membres du comité est accessible en ligne sur

http://www.etudesettravaux.iksiopan.pl

\author{
RÉDACTION TECHNIQUE \\ Jadwiga Iwaszczuk \\ Maciej Makowski
}

REVUE DES TEXTES EN ANGLAIS

Jo Harper 
ÉTUDES et TRAVAUX XXXIII 
INSTYTUT KULTUR ŚRÓDZIEMNOMORSKICH I ORIENTALNYCH POLSKIEJ AKADEMII NAUK

\title{
STUDIA i PRACE
}

XXXIII

\author{
ROIKŚSiO \\ ESOPAN \\ WARSZAWA \\ 2020
}


INSTITUT DES CULTURES MÉDITERRANÉENNES ET ORIENTALES DE L'ACADÉMIE POLONAISE DES SCIENCES

\section{ÉTUDES et TRAVAUX}

XXXIII

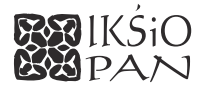

VARSOVIE

2020 
Publication scientifique financée dans le cadre du programme du Ministre de la Science et de l'Éducation Supérieure

« Programme National de Développement de l'Humanistique » pour les années 2016-2021 (projet no 3bH 150099 83)

\title{
UARODOWY PROGRAM ROZWOJU HUMANISTYKI
}

\author{
Copyright (C) \\ Instytut Kultur Śródziemnomorskich i Orientalnych PAN \\ et les Auteurs \\ Warszawa 2020
}
ISSN 2084-6762
(jusqu'en 2011 : 0079-3566)
e-ISSN 2449-9579
Version première en papier, imprimée en Pologne - 150 copies
Version électronique accessible sur
http://www.etudesettravaux.iksiopan.pl

Édition: Polskie Towarzystwo Historyczne et Wydawnictwo Neriton, Warszawa

Conception générale de la couverture : J. Iwaszczuk

Photographie de couverture : J. Pablo Moreira (C) Thutmosis III Temple Project

(Henket-ankh, le temple des Millions d'Années de Thoutmosis III, Louxor) 


\section{Table des matières}

Editorial (par Ewa Laskowska-Kusztal) ................................................................... 7

MirosŁaW BARWIK

Two Portraits of Senenmut in the Hatshepsut Temple at Deir el-Bahari

MirosŁaW BARWIK

New Prayers and Invocations to Hathor among Unpublished Dipinti

from the Thutmose III Temple at Deir el-Bahari

LiNDA CHAPON

The Decoration of the Columns and Pillars from the Henket-ankh of Thutmose III

(Western Thebes)

Abraham I. Fernández Pichel

Quelques blocs ptolémaïques inédits de la cour du IX pylône du domaine

d'Amon à Karnak

Amgad Joseph

The Stela of Haremwia, Chief of the Provisioning Sector of the Temple Workshop

(CG 34079 / JE 22011)

EWA JÓZEFOWICZ

Ramesside Inscriptions and Preparatory Sketches in the Western Wall of Portico

of Obelisks of Hatshepsut's Temple at Deir el-Bahari

Miral LASHIEN

Donkeys in the Old and Middle Kingdoms According to the Representations

and Livestock Counts from Private Tombs

AleKsandra Pawlikowska-Gwiazda

Christian Secondary Epigraphy in the Temple of Hatshepsut. Some New Remarks

KRZYSZTOF RADTKE

Square Grids in the Tomb of Akhethotep - Questions and Doubts

Myriam Seco Álvarez, JaVier Martínez Babón

The Temple of Millions of Years of the Pharaoh Thutmose III (Luxor). An Update on the Research 